University of Nebraska - Lincoln

DigitalCommons@University of Nebraska - Lincoln

Faculty Publications from the Harold W. Manter Laboratory of Parasitology

$7-1-2002$

\title{
New and Known Species of Litomosoides (Nematoda: Filarioidea): Important Adult and Larval Characters and Taxonomic Changes
}

\author{
Ricardo Guerrero \\ Universidad Central de Venezuela \\ Coralie Martin \\ Muse'um National d'Histoire Naturelle et Ecole Pratique des Hautes Etudes \\ Scott Lyell Gardner \\ University of Nebraska - Lincoln, slg@unl.edu \\ Odile Bain \\ Museum National d'Histoire Naturelle et Ecole Pratique des Hautes Etudes, bain@mnhn.fr
}

Follow this and additional works at: https://digitalcommons.unl.edu/parasitologyfacpubs

Part of the Parasitology Commons

\begin{abstract}
Guerrero, Ricardo; Martin, Coralie; Gardner, Scott Lyell; and Bain, Odile, "New and Known Species of Litomosoides (Nematoda: Filarioidea): Important Adult and Larval Characters and Taxonomic Changes" (2002). Faculty Publications from the Harold W. Manter Laboratory of Parasitology. 6.

https://digitalcommons.unl.edu/parasitologyfacpubs/6
\end{abstract}

This Article is brought to you for free and open access by the Parasitology, Harold W. Manter Laboratory of at DigitalCommons@University of Nebraska - Lincoln. It has been accepted for inclusion in Faculty Publications from the Harold W. Manter Laboratory of Parasitology by an authorized administrator of DigitalCommons@University of Nebraska - Lincoln. 


\title{
New and Known Species of Litomosoides (Nematoda: Filarioidea): Important Adult and Larval Characters and Taxonomic Changes
}

\author{
Ricardo Guerrero, ${ }^{1}$ Coralie Martin, ${ }^{2}$ Scott L. Gardner, ${ }^{3}$ And Odile Bain ${ }^{2,4}$ \\ ${ }^{1}$ Faculdad de Ciencias, Instituto de Zoologia Tropical, Universidad Central de Venezuela, P.O. Box 47058, \\ 1041A Caracas, Venezuela, \\ ${ }^{2}$ Parasitologie Comparée et Modèles Expérimentaux, Associée à 1'INSERM (U445), Institut de Systématique, \\ CNRS FR 1541, Muséum National d'Histoire Naturelle et Ecole Pratique des Hautes Etudes, 61 Rue Buffon, \\ 75231 Paris Cedex O5, France, and \\ ${ }^{3}$ Harold W. Manter Laboratory of Parasitology, W-529 Nebraska Hall, University of Nebraska-Lincoln, \\ Lincoln, Nebraska 68588-0514, U.S.A. (e-mail: slg@unl.edu)
}

ABSTRACT: During field surveys in Venezuela, Peru, and French Guiana, species of Litomosoides were recovered from bats and from a didelphid marsupial. Their morphology was studied, giving particular attention to the head and caudal papillae, the spicules (used to distinguish the carinii and sigmodontis groups of Litomosoides), and the microfilariae. Litomosoides wilsoni sp. n. from the short-tailed opossum Monodelphis emiliae is described from Peru; Litomosoides brasiliensis, Litomosoides chandleri, and Litomosoides guiterasi from bats are redescribed, and new hosts are recorded. For the first time, larval stages were recovered from bats (1 male and 1 female fourth-stage larvae of Litomos. brasiliensis). Litomosoides solarii sp. n. from the fringe-lipped bat Trachops cirrhosus (Phyllostomidae) in Peru is distinguished from the other species by its peculiar microfilaria (the male is unknown). Filaria serpicula from Phyllostomus sp. in Brazil is renamed Litomosoides serpicula (Molin, 1858) comb. n. This study confirms the close morphological resemblance between the species of Litomosoides from flying and terrestrial mammals and reinforces the hypothesis of host-switching in the evolution of this genus. The 2 North American species of Litomosoides from the Geomyidae were reexamined and are peculiar in several adult and microfilarial characters that resemble those of Litomosa, parasitic in Old World bats. The following new combinations are proposed: Litomosa westi (Gardner and Schmidt, 1986) comb. n. and Litomosa thomomydis (Gardner and Schmidt, 1986) comb. n. However, Litomosa and Litomosoides have in common a thick buccal capsule embedded posteriorly in the esophagus, which suggests that they are closely related. Litomosoides andersoni, a parasite of a caviomorph rodent, likely results from conflation of a species of Litomosoides and one of Ackertia.

KEY WORDS: Litomosoides wilsoni sp. n., Litomosoides solarii sp. n., Litomosa, Ackertia, bats, rodents, marsupials, host-switching, phylogeny.

Species of Litomosoides Chandler, 1931, are filarioid nematodes occurring in the Nearctic and Neotropical regions. They exhibit an interesting host-spectrum that is "non-coherent" (sensu Chabaud, 1982) in that they occur in phylogenetically distinct groups of both flying and terrestrial mammals. Two species of Litomosoides are parasitic in marsupials, about 12 in bats (mainly the phyllostomids), and approximately 17 in rodents. The latter are found mainly in sigmodontine murids, but a few species are also known in sciurids, echimyids, and ctenomyids (Notarnicola et al., 2000). Two species are also found in geomyids, but they are considered very specialized (Gardner and Schmidt, 1986).

Interest in Litomosoides has increased recently because Litomosoides sigmodontis Chandler, 1931, unlike other filarioid nematodes, com-

\footnotetext{
${ }^{4}$ Corresponding author (e-mail: bain@mnhn.fr).
}

pletes its development in laboratory mice (Petit et al., 1992) and is thus a useful model for studying human filariases (Allen et al., 2000; Martin et al., 2000).

Bain and Philipp (1991) suggested that this exceptional capacity to develop in mice is a result of the phylogenetic history of Litomosoides. They hypothesized that Litomosoides originated in Neotropical bats and subsequently diversified in Neotropical terrestrial mammals when sigmodontine murids, migrating from North America at the time of the Great American Interchange during the Pleistocene, began a rapid and extreme burst of speciation in South America (Marshall, 1979). The importance of hostswitching in the evolution of Litomosoides is also emphasized in the recent phylogenetic analysis of Brant and Gardner (2000), who found that there is essentially no phylogenetic host specificity among these nematodes. 
However, important characters such as the cephalic sensory organs and the male caudal ornamentation (area rugosa) are often insufficiently known. Moreover, it is necessary to verify by the study of the spicules if the 2 morphological types, carinii and sigmodontis, identified in $\mathrm{Li}$ tomosoides by Bain et al. (1989) from terrestrial mammals also exist in bats (Bain et al., 1989).

To understand the evolution of the genus $\mathrm{Li}$ tomosoides, additional and more detailed morphological data is necessary. We studied 14 samples of specimens derived from field surveys in Venezuela, Peru, and French Guiana. From these, 5 species of Litomosoides were identified. A new species was recovered from a didelphid marsupial, and 3 known species and 1 new species were recovered from different bats. We also examined the original material of Filaria serpicula Molin, 1858, parasitic in a bat in Brazil, and the 2 species parasitic in geomyids (pocket gophers).

During the course of the study, we sometimes observed slight morphological differences in a species between samples from diverse hosts or geographic origins; this suggests the possibility of greater diversity than is usually accepted for the genus, but this is not our present concern. More samples fixed under similar conditions will be necessary to address this question adequately. The 2 larval stages recovered for the first time from a bat are particularly interesting and have phylogenetic significance.

\section{MATERIALS AND METHODS}

\section{Hosts}

Hosts of the newly studied materials were captured in different stations, in northern Venezuela, Parque Nacional Guatopo (Agua Fria), Miranda state, during 1981, as part of a study of ectoparasites of bats (Guerrero, 1993); in eastern Peru, Parque Nacional Manu (Pakitza), Madre de Dios state, during 1992, and the lower Urubamba region (San Martin 3-well site and Camisea), Cuzco state, during 1997, in both cases within a field research program directed by the Smithsonian Institution; in French Guiana, in the central (Nouragues) and northwest (St. Elie) regions during the long-term program of Tropical Ecology (Ecotrop) performed by several institutions, Centre National de la Recherche Scientifique (CNRS), Muséum National d'Histoire Naturelle (MNHN), Institut sur la Recherche et le Développement (IRD), and Centre de Coopération Internationale en Recherche Agronomique pour le Développement (CIRAD). Environmental characteristics of these stations are presented in a document on national parks dated from 1992 for Venezuela, in Wilson and Sandoval (1996) and Dallmeier and Alonso
(1997) for Peru, and in Brosset et al. (1996) for French Guiana. Hosts were dissected just after their capture (Peru, Venezuela) or after fixation in alcohol or formalin (Venezuela, French Guiana). Host names used are consistent with those used in Wilson and Reeder (1993). Host field numbers are presented in parentheses.

\section{Collection centers}

Types and studied material are deposited in 3 collection centers: Colección de Parasitología, Museo de Biología (CP-MBUC), Universidad Central de Venezuela, Caracas, Venezuela (accession numbers are those of the field collection); Laboratorio de Helmintología, Museo de Historia Natural (MUSM), Universidad Nacional Mayor de San Marcos, Lima, Peru; Muséum National d'Histoire Naturelle (MNHN), Paris, France (numbers followed by letters are of this collection). Filaria serpicula was examined in the Collection of Evertebrata-Varia, numbers 6322-6324, at the Naturhistorisches Museum Wien (NMW), Vienna, Austria.

\section{Definitions of the morphological characters studied}

The morphological study was performed with fixed specimens cleared in lactophenol and examined under a light microscope. All the specimens of each sample were observed. Drawings were made using a drawing tube. Sensory organs of the head were studied and illustrated in median, lateral, and apical views from several specimens of both sexes. Amphids, lateral cuticular thickenings of the body, and the lumens of the esophagus were used to orient the head, as described in Notarnicola et al. (2000). The structure of the buccal capsule is defined by its length, its width (maximum external diameter), the ratio of length to width, and the shape of its walls (which can be thin or thick or have well-defined and thick rings). The overall shape of the buccal cavity was studied and considered separately. Microfilariae were removed from the uteri near the vulva of females for study in a fully developed state. Spicules were dissected from 1 or 2 male specimens to observe the membranous parts more completely; the arrangement of caudal papillae was studied in ventral view; the structure of the area rugosa was studied and its length measured (anterior and posterior extremities from the cloacal aperture).

Measurements are given as follows: from adults, mean followed by minimum-maximum values in parentheses; in microfilariae, mean length \pm standard deviation and extreme values of width. For a new species, holotype and allotype measurements are given first. When necessary, measurements of samples from different host species are presented separately. Length of adults is given in millimeters, all other measurements are in micrometers.

Names of known species of Litomosoides are consistent with those in Bain et al. (1989) and Notarnicola et al. (2000).

\section{RESULTS}

The characters common to the species studied are as follows. Body attenuated in anterior re- 
gion. Head attenuated in lateral view but often round in median view. Mouth minute, slightly depressed. Long channel of amphids conspicuous. Buccal capsule always composed of a main strongly cuticularized part and an anterior less cuticularized segment corresponding to invagination of the body cuticle. Posterior part of buccal capsule always within the apex of the esophagus. Lateral thickening of body cuticle beginning posterior to buccal capsule.

Area rugosa beginning anterior to cloacal aperture and extending beyond the coiled region of the tail, always composed of transversal bands of short longitudinal cuticular crests. Right spicule strongly cuticularized through its distal extremity with a subterminal dorsal hook or a cap, and a conspicuous dorsal heel, as defined in the carinii group of Litomosoides (Bain et al., 1989), except in the 2 species from Geomyidae. Microfilariae: body straight; head attenuated and terminated in a salient hook, except in the 2 species from Geomyidae.

\section{Litomosoides wilsoni sp. $\mathrm{n}$.} (Figs. 1-16)

\section{Description}

General: Anterior end conical. Head with 4 externo-labial papillae arranged in a rectangle stretched dorso-ventrally and 2 ventral cephalic papillae close to the amphids. Buccal cavity tubular; buccal capsule longer than broad; external and often internal edges of walls irregularly crenated.

Male: Three or 4 pairs of well-developed caudal papillae arranged in 2 almost symmetric lines. Left spicule with large handle; proximal part of lamina devoid of longitudinally folded membranous alae, distal part a membranous flap. Measurements (holotype, 1 paratype, and posterior fragment of another paratype) are as follows. Length 23.6 and 23.0. Maximum width 108 (108-109). Buccal capsule 19 and 16 long, 12 and 9 wide; ratio of length to width 1.58 and 1.78. Nerve ring 278 and 285 from apex. Esophagus 522 and 474 long. Tail 150 (113-150) long, width at cloaca $61(59-59)$. Area rugosa from 450 and 452 to 1,590 and 1,800 , ridges $2-3$ high, distance between ridges $9-12$. Left spicule 281 (278-282) long, handle 178 (166-188) long. Right spicule 118 (126-137) long. Spicular ratio $2.33(2.03-2.24)$.
Female: Postesophageal vulva, subspherical vagina; tail attenuated, curved ventrad; posterior extremity, which may be dorsoventrally depressed, lined with thick cuticle; phasmids dispersed. Measurements (allotype) are as follows. Length 105. Maximum width 294. Buccal capsule 21 long and 11 wide; ratio of length to width 1.91. Esophagus 546 long. Nerve ring 294 from anterior end. Vulva 1,110 to apex. Vagina 74 long by 78 wide. Tail 400 long; width at anus 89.

Microfilariae: Posterior extremity attenuated and terminal anucleate, pointed tail. Length (from allotype) $61.8 \pm 2.5$, width 4.0-4.5 $(n=$ $10)$.

\section{Taxonomic summary}

Type host: Monodelphis emiliae (Thomas, 1912) (Didelphidae).

Type locality/collection date: San Martin 3-well site, Lower Urubamba Region, Cuzco, Peru $\left(11^{\circ} 47^{\prime} \mathrm{S} ; 72^{\circ} 42^{\prime} \mathrm{W}\right) 474 \mathrm{~m}$, field number $(58$ 010597), 8 May 1997.

Infection site: Abdominal cavity.

Prevalence and intensity of infection: 1/1.

Specimens deposited: Male holotype MUSM 1739, female allotype (in 2 parts) MUSM 1740, a male paratype CP-MBUC 58-010597, a posterior part of another male paratype, and a female paratype MNHN 228 HS.

Etymology: Named after Don E. Wilson, who directed the mission in Lower Urubamba and collected many hosts, in recognition of his contribution to Neotropical mammalogy.

\section{Remarks}

The 9 previously described species of the carinii group of Litomosoides all differ from our material, as discussed subsequently.

Species in bats: Litomosoides brasiliensis Lins de Almeida, 1936, first described from Myotis sp. in Brazil, has a buccal capsule with 2 rings, huge spicules, caudal papillae in tandem, and greater reduction of the head papillae.

Litomosoides guiterasi (Pérez, 1934), first described from Artibeus jamaicensis parvipes Renn, 1902, in Cuba, has a shorter body and spicules compared with our specimens, a longer and thinner buccal capsule, fewer caudal papil- 

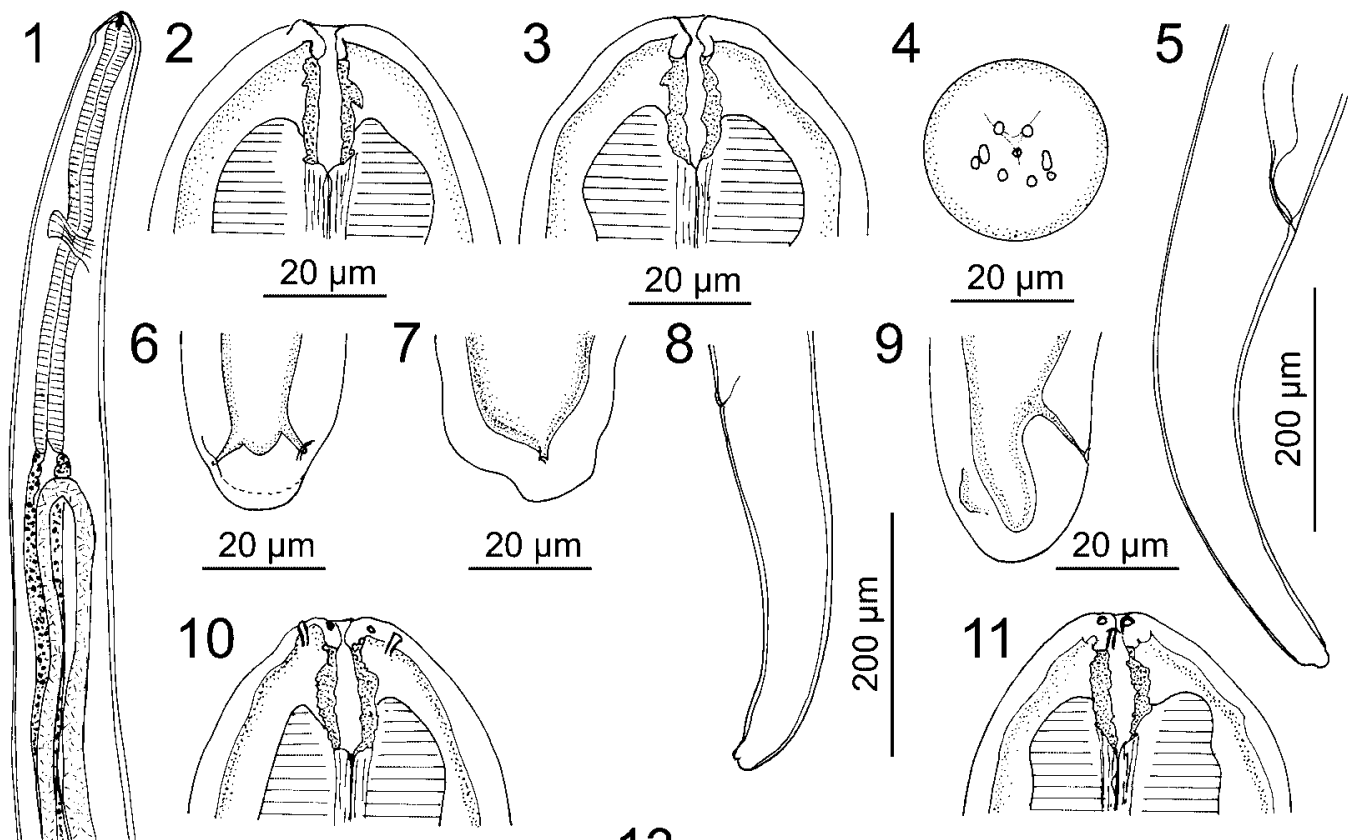

13
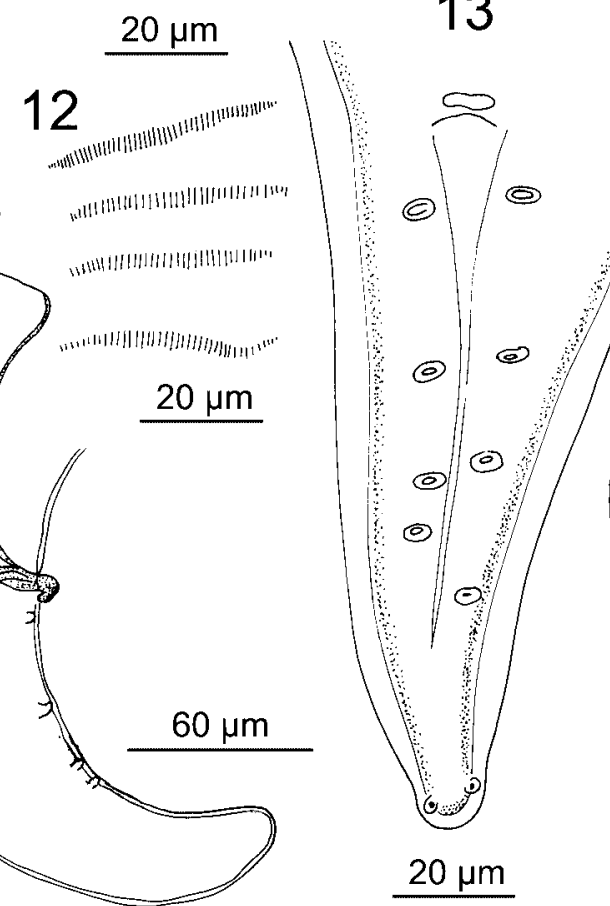

$20 \mu \mathrm{m}$

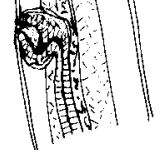

\section{$150 \mu \mathrm{m}$}
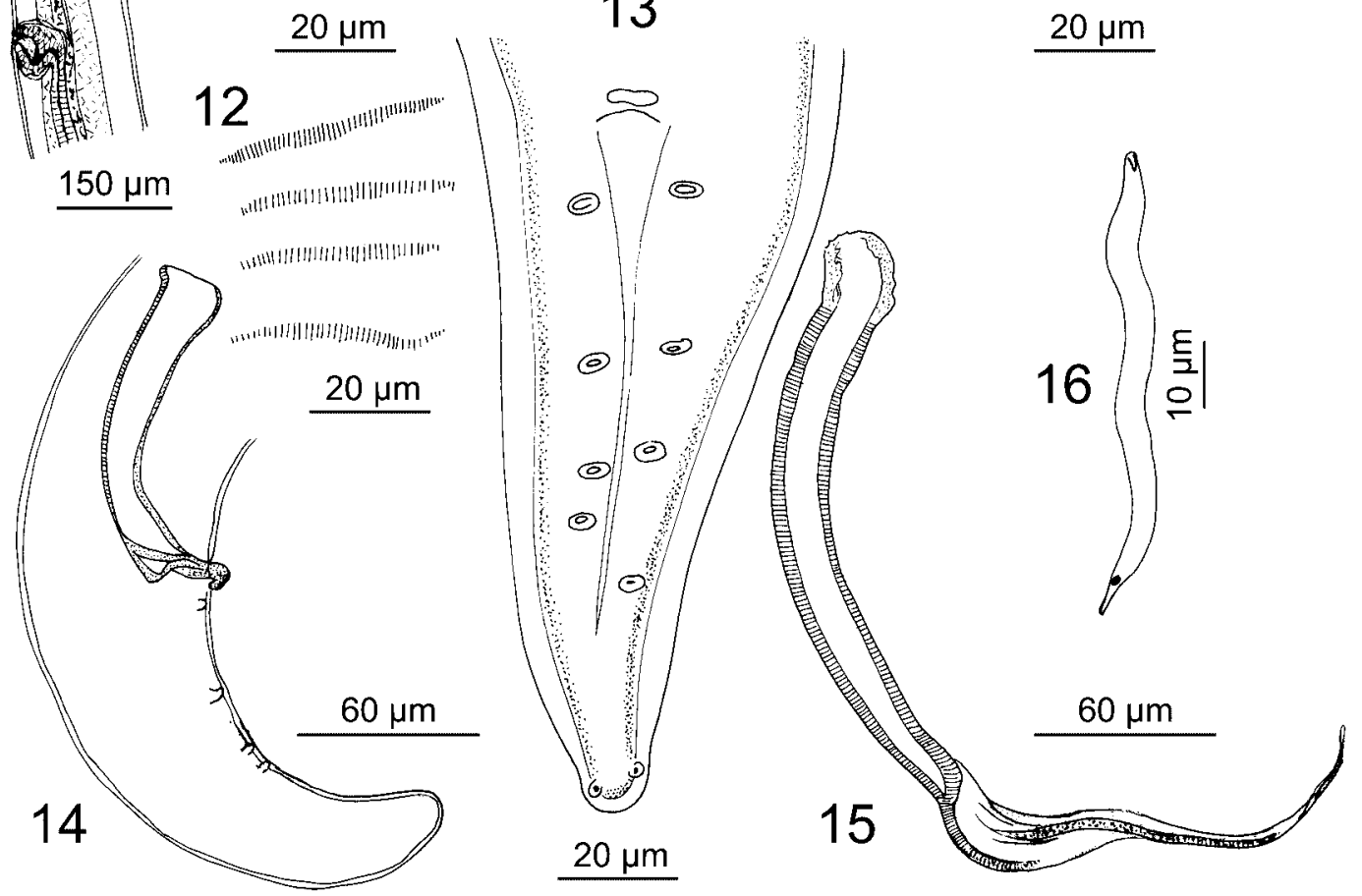

Figures 1-16. Litomosoides wilsoni sp. n. from Monodelphis emiliae in Peru. 1-4. Female (paratype MNHN 228HS). 1. Anterior region, lateral view. 2, 3. Buccal capsule. 4. Head, apical view. 5-7. Female (allotype MUSM 1740). 5. Tail. 6, 7. Posterior extremity, ventral and right view, respectively. 8, 9. Female (paratype MNHN 228HS). 8. Tail, lateral view. 9. Posterior extremity, ventral view. 10, 11. Male (holotype MUSM 1739), head, ventral and lateral view, respectively. 12-15. Male (paratype MNHN 228HS). 12. Area rugosa, ventral view. 13. Tail, ventral view. 14. Tail with right spicule, lateral view. 15. Left spicule, lateral view. 16. Microfilaria from allotype. 
lae, and a short tail, and the vulva is at the level of the esophagus. (Note: the correct author's name of this species is not Vigueras, as is usually given following Sandground [1934], but Pérez.) Litomosoides chandleri Esslinger, 1973, a parasite of Artibeus jamaicensis Leach, 1821, in Colombia, is much shorter than our specimens, with a bottle-shaped buccal cavity, shorter spicules, and a right spicule that is shaped differently, and the lateral lines of the adult are ornamented with a row of tiny bosses; the microfilariae have a thick rounded tail (for these first 3 species, see also the redescriptions in this study). Litomosoides molossi Esslinger, 1973, from Molossus molossus (Pallas, 1766) in Colombia, has similar cuticular ornamentation to Litomoso. chandleri, with a very small body and spicules, and a long thin buccal capsule.

Species in rodents: Litomosoides scotti Forrester and Kinsella, 1973, from Oryzomys palustris (Harlan, 1837) in the United States (Florida), has salient amphids and an exceptionally thickened peribuccal cuticle (Bain et al., 1989), a short buccal capsule with a prominent ring, and short spicules (left 185-261 $\mu \mathrm{m}$ and right 77-109 $\mu \mathrm{m}$ long). Litomosoides silvai Padilha and Faria, 1977, a parasite of the rat Bolomys lasiurus (Lund, 1841) (=Akodon arviculoides Wagner, 1842) in Brazil (Rio de Janeiro), has a buccal cavity with 2 short rings, a tail with a subterminal constriction in the female, and adanal first pairs of caudal papillae in the male (see redescriptions by Moraes Neto et al. [1996] and Notarnicola et al. [2000]; from Akodon cursor [Winge, 1887], also from Brazil). Litomosoides bonaerensis Notarnicola et al., 2000, from Oligoryzomys delticola (Thomas, 1917) in Argentina (La Plata), has a buccal capsule with a ring, labial papillae jointed in the median line, the third pair of caudal papillae situated in tandem in the male, and longer microfilariae, which are 66-76 $\mu \mathrm{m}$ instead of 58-65 $\mu \mathrm{m}$. Litomosoides carinii (Travassos, 1919), described from Sciurus $\mathrm{sp}$. in Brazil, has a smaller body and a short, not crenated, buccal capsule, and the left spicule has a long handle.

Species in marsupials: Litomosoides petteri Bain, Petit, and Berteaux, 1980, from Micoureus demararae (Thomas, 1905) (=Marmosa cinerea [Temminck, 1824]) in Brazil (Rio de Janeiro), has the 8-head papillae symmetrically arranged, a buccal capsule with a ring, the vulva at the level of the esophagus, and longer microfilariae (78-83 $\mu \mathrm{m}$ compared with 58-65 $\mu \mathrm{m}$ ).

A few species of Litomosoides, the males of which are unknown and cannot be placed in a defined group of Litomosoides, carinii or sigmodontis as defined by Bain et al. (1989), are also distinct from our material. They are parasitic in bats. Litomosoides artibei Esslinger, 1973, a parasite of Artibeus cinereus (Gervais, 1856) from Colombia (Valle), has a long narrow buccal cavity (30 $\mu \mathrm{m}$ long, buccal capsule ratio 6.8 compared with 1.9) with straight walls, thickened only at the anterior extremity, and microfilariae with a thick, long flexed tail. Litomosoides colombiensis Esslinger, 1973, from Platyrrhinus dorsalis (Thomas, 1900) (previously Vampyrops dorsalis Thomas, 1900) in Colombia (Valle), has a microfilaria that tapers posteriorly to form a long, narrow tail. The Litomosoides sp. of Chitwood (1938), from Artibeus jamaicensis yucatanicus (Allen, 1904) in Yucatan, is smaller (female $15 \mathrm{~mm}$ long), with a shorter buccal cavity $(12 \mu \mathrm{m})$ and a long tail $(583 \mu \mathrm{m})$. Litomosoides caliensis Esslinger, 1973, from Sturnira lilium (E. Geoffroy, 1810) in Colombia (Valle), has a microfilaria of length similar to that of our material (mean $60 \mu \mathrm{m}$ ) but a thicker posterior extremity and no anucleate point.

Including the species described here, 3 species of Litomosoides are now known from didelphid marsupials. They do not represent a monophyletic group: Litomosoides barretti Muller, 1980, from Mi. demararae (=Mar. cinerea), belongs to the sigmodontis group (Bain et al., 1989), and the 2 species of the carinni type are either primitive, with 8-head papillae symmetrically arranged (Litomoso. petteri, also from Mi. demararae), or derived, with reduction of the cephalic papillae (Litomoso. wilsoni from Mon. emiliae).

\section{Litomosoides brasiliensis Lins de Almeida, 1936 \\ (Figs. 17-31, 43-54)}

\section{Material studied}

Six samples, from 2 countries and 4 species of bats. From Peru: Camisea, Cuzco $\left(11^{\circ} 52^{\prime} \mathrm{S}\right.$; $\left.72^{\circ} 47^{\prime} \mathrm{W}\right) 579 \mathrm{~m}$, host Carollia perspicillata (Linnaeus, 1758) MUSM 1751, 12 May 1997, several males and several females, MNHN 341 SE; from (289-010597), 23 May 1997, 2 males, 

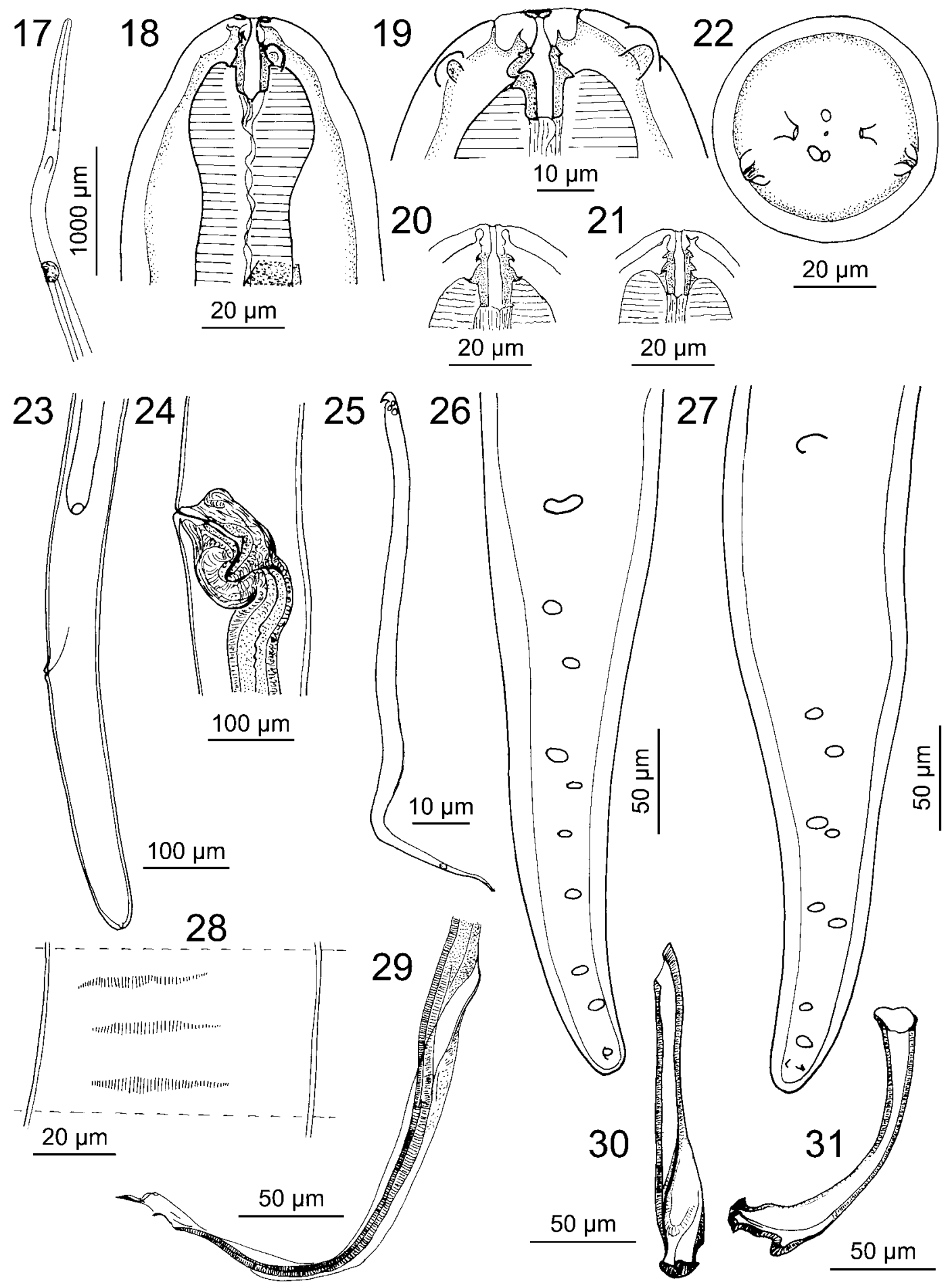

Figures 17-31. Litomosoides brasiliensis from Carollia perspicillata in Peru (MNHN 341 SE). 17-25. Female. 17. Anterior region (anterior-most coil of uteri indicated). 18. Anterior extremity, right lateral view. 19. Head, ventral view. 20, 21. Buccal capsules of 2 other specimens. 22. Head, apical view. 23. Tail, lateral view. 24. Vagina, lateral view. 25. Microfilaria. 26-31. Male. 26, 27. Tail of 2 males, ventral view. 28. Area rugosa, ventral view. 29. Lamina of left spicule. 30, 31. Right spicule, ventral and lateral view, respectively. 
3 females, CP-MBUC 289-010597; from (311010597), 25 May 1997, 1 female, CP-MBUC 311-010597; host St. lilium (86-010597), 10 May 1997, 8 males, 6 females, MUSM 1752; Paquitza, Parque Nacional Manu, host Anoura caudifer (E. Geoffroy, 1818) (159-100292), 21 February 1992, 1 mature female and 2 late larval stages, CP-MBUC 159-100292; from French Guiana: Piste de St. Elie $\left(5^{\circ} 18^{\prime} \mathrm{N}\right.$; 53 $\left.04^{\prime} \mathrm{W}\right) 200$ $\mathrm{m}$, host Lionycteris spurrelli Thomas, 1913, (179), 8 February 1984, 1 male (without anterior end), MNHN 387 SE.

\section{Redescription}

General: Characters established with the specimens recovered from $\mathrm{Ca}$. perspicillata. Set of head papillae: 1 dorsal and 2 joint ventral external labial papillae at the level of the mouth; amphids slightly posterior; 2 large latero-ventral cephalic papillae at midlength of the buccal capsule. Bottle-shaped buccal cavity; cuticular walls of the buccal capsule usually with 2 rings, one thick, triangular in longitudinal section, lying on the apex of the esophagus, the other anterior, smaller, rarely inconspicuous; both rings sometimes with anterior external aspect protruding backwards. Abnormal capsules rather frequent, irregular, and asymmetric. Some variations were observed in the specimens from other bat species: the buccal capsule in St. lilium is often longer and the rings more separated; in 2 specimens, a male and a female, the rings are absent, and the buccal cavity is tubular. The single female from An. caudifer has an asymmetric buccal capsule and a cavity that is slightly wider.

Male: Four pairs of postcloacal papillae, almost aligned on the median line, the anterior pair more or less far from the cloacal aperture. Lamina of left spicule with long membranous terminal flap. Measurements of 2-4 specimens from $\mathrm{Ca}$. perspicillata from $341 \mathrm{SE}$ are as follows. Length 42.8, 49.3. Maximum width 121, 132 ; at nerve ring 42, 48; at esophageal-intestinal junction 55, 66. Buccal capsule 15 (13-16) long, 10.3 (10-11) wide; buccal capsule ratio 1.45 (1.3-1.6). Nerve ring 420 (378-480) from apex. Esophagus 660 (624-717) long. Tail 272.2 (257-297) long and width at cloaca 69 (60-77). Area rugosa from $457(380-522)$ to 1,955 $(1,755-2,075)$, transversal ridges 1-1.5 high, distance between bands $8-12$. Left spicule 478 (464-491) long, handle 207 (199-217) long.
Right spicule 160 (154-167) long. Spicular ratio 2.99 (2.89-3.08). Measurement of 7 specimens from St. lilium from (86-010597) are as follows. Length 54.6, 58.4. Maximum width 120 (105$127)$; at nerve ring 46 (42-48); at esophagealintestinal junction 59 (55-66). Buccal capsule 20 (18-24) long, 10 (8-12) wide; buccal capsule ratio 2.1 (1.0-3.0). Nerve ring 215 (195-230) from apex. Esophagus 643 (636-655) long. Tail 266 (242-297) long and width at cloaca 67 (6077). Area rugosa from $532(504-540)$ to 1,760 $(1,655-1,860)$, transversal ridge $1-1.5$ high, distance between bands $8-12$. Left spicule 485 (464-510) long, handle 215 (199-247) long. Right spicule 163 (157-168) long. Spicular ratio 2.97 (2.82-3.06). Measurements of 1 specimen from Lio. spurrelli from 387 SE: tail 360 long; left spicule 555 long, handle 225 long; right spicule 195 long.

Female: Vagina usually subspherical in Ca. perspicillata, elongated in half of the females from St. lilium; in An. caudifer, elongated vagina and vulva located particularly far behind the esophagus. Tail usually straight, except in the female from An. caudifer. Measurements of 2 specimens from $\mathrm{Ca}$. perspicillata from $341 \mathrm{SE}, 1$ from (311-010597) are as follows. Length 106.5 (95.2-118.2). Maximum width 239 (228-255); at nerve ring 65 (52-96); at esophageal-intestinal junction 106 (92-112); at vulva 114 (98140). Buccal capsule 20.3 (18-23) long and 12 (11-13) wide; buccal capsule ratio 1.70 (1.541.92). Esophagus 853 (824-876) long. Nerve ring 421 (393-441) from anterior end. Vulva $2,199(2,052-2,315)$ to apex. Vagina 105 (90116) long by 55 (47-56) wide. Tail 365 (318448) long; width at anus 70 (66-77). Measurements of 3 specimens from St. lilium from (86010597) are as follows. Length 157 (142.9162). Maximum width 241 (230-250); at nerve ring 65 (52-96); at esophageal-intestinal junction 106 (92-122). Buccal capsule 21 (17-25) long and 11 (10-12) wide; buccal capsule ratio 1.9 (1.7-2.5). Esophagus 858 (830-885) long. Nerve ring 284 (258-320) from anterior end. Vulva 2,728 $(2,525-2,800)$ to apex. Vagina 105 (90-116) long by 55 (47-56) wide. Tail 412 (355-445) long; width at anus 75 (70-78). Measurements of 1 specimen from An. caudifer from (159-100292) are as follows. Length 171.1. Maximum width 280; at nerve ring 105; at esophageal-intestinal junction 120; at vulva 230 . 
Buccal capsule 18 long and 13 wide; buccal capsule ratio 1.38. Esophagus 915 long and 35 wide. Nerve ring 480 from anterior end. Vulva 3,420 from apex. Vagina 130 long by 50 wide. Tail 385 long; width at anus 95.

Microfilariae: Body greatly attenuated posteriorly. From Ca. perspicillata from 341 SE: 94.5 $\pm 4.2(n=9)$; from 2 females from (289010597): length $79.7 \pm 4.9(n=6)$ and $74.9 \pm$ $7.5(n=7)$, global mean length $84.2 \pm 10.5$, width 3.5-4. From St. lilium from (86-010597): mean length from 5 females $71.8 \pm 0.9(n=$ 30); from the female with capsule devoid of ring: length $72 \pm 3.2$. From An. caudifer from (159-100292): 103, $108(n=2)$.

\section{Remarks}

The specimens from $C a$. perspicillata in Peru are identified to Litomoso. brasiliensis, a wellcharacterized species with several distinguishing male morphological features: large spicules, distal part of the right spicule with a terminal cap and a pronounced dorsal heel, which have been constantly described by the authors (Lins de Almeida [1936], with the unique male representing the type material recovered from Myotis sp. in Brazil (Matto Grosso); Rego [1961], with specimens recovered from Ca. perspicillata, Glossophaga soricina (Pallas, 1766), Glossophaga sp., and unidentified Phyllostomidae in Brazil; Diaz-Ungria [1963], from Ca. perspicillata, Phyllostomus sp., and Myotis sp. in Venezuela; Esslinger [1973], from Ca. perspicillata in Colombia). The buccal capsule with 2 rings is also diagnostic; these rings were observed in the original description (Lins de Almeida, 1936) and have been regularly noted or drawn in later descriptions of the female. The male papillae studied in ventral view by Diaz-Ungria (1963) are aligned on the median line as in our specimens. In the female the vulva is far behind the esophagus, the vagina is subspherical, and the tail is long and cylindrical, as described by Rego (1961) and Esslinger (1973). The microfilariae described only by Esslinger (1973) have a size and shape (mean 92, extremes 80-104) similar to those of our specimens.

Based on the shape and size of the spicules, the specimens from St. lilium are also identified as Litomoso. brasiliensis; however, some morphological particularities were noted. These specimens show more variation in the buccal capsule and vagina; the mean length of microfilariae is less than the smallest length given by Esslinger (1973) and observed in our material from Ca. perspicillata. In An. caudifer the single adult female has the vulva far behind the esophagus but close to the longest distance given by Esslinger (1973), and the microfilaria is as long as the maximum length given by this author; the unique male recovered is at the fourth molt, and the newly formed right spicule showed the typical shape of Litomoso. brasiliensis (Fig. 4142); however, the caudal papillae differ slightly (their number is reduced and the last posterior papillae are jointed medially [Fig. 39]).

Sturnira lilium, An. caudifer, and Lio. spurrelli are new hosts for Litomoso. brasiliensis, of which the distribution is now extended to Peru and French Guiana. However, it is probable that what is thought of as Litomoso. brasiliensis actually represents a complex of species. If the poorly described Litomosoides caballeroi Gracia, 1960, could be considered as a synonym of Litomoso. brasiliensis, then Litomosoides carolliae Caballero, 1944, from Carollia perspicillata azteca (Hahn, 1907) in Mexico (Caballero, 1944) could be a close species (Diaz-Ungria, 1963); for a definitive interpretation a description of its microfilariae is necessary.

The same logic is applied to $F$. serpicula, a parasite of Phyllostoma spp. in Brazil (Molin, 1858). This species, reexamined, was found to belong to the genus Litomosoides and to resemble Litomoso. brasiliensis with its spicules. Filaria serpicula is hereby recognized as Litomoso. serpicula $\mathrm{n}$. comb. In the absence of data on the microfilariae and with the arrangement of caudal papillae in ventral view, we prefer not to create a synonymy of Litomoso. brasiliensis with this oldest taxon.

\section{Late Larval Stages of Litomosoides brasiliensis} (Figs. 32-42)

\section{Material studied}

Part of the sample from An. caudifer (159100292): 1 female larva and 1 male larva, both at the fourth molt, CP-MBUC 159-100292.

\section{Description}

In the 2 larvae the process of molting is identified because of the double cuticular lining of the buccal capsule. Molting is beginning in the 
female larva, and the tissues surrounding the buccal capsule are typically vacuolated. Molting is almost finished in the male.

Fourth-stage female larva: Buccal cavity narrow and cylindrical, wall of buccal capsule regularly thin. Glandular esophagus slightly differentiated. Vulva slightly posterior to the esophageal-intestinal junction; vagina elongated (with tall juvenile epithelial cells lining the lumen). Tail cylindrical with round extremity; phasmids subterminal. Length 29.2 , width 110 , buccal capsule 24 long; esophagus 620 long with muscular part 230 long, nerve ring and vulva 250 and 980 from apex, tail 280 long.

Fourth-stage male larva: Buccal capsule with a thick ring present; right spicule with the characteristic dorsal heel and terminal cap of Litomoso. brasiliensis, although still weakly cuticularized; left spicule with lamina simple in shape; postcloacal papillae of the 2 first pairs in tandem on the median line, except the last and the third pairs with papillae jointed on the median line; subterminal phasmids. Length 17.85 , width 100 , buccal capsule 24 long; esophagus 620 long with muscular part 230 long, nerve ring 280 from apex; tail 225, left spicule 370 (handle 200), right spicule 175 .

\section{Remarks}

The larval stages recovered from An. caudifer provide new and interesting information on the ontogenesis of species of Litomosoides from bats. The buccal cavity of the fourth-stage larva is long and tubular, and the buccal capsule is regularly thin, with the "rings" appearing only at the early adult stage. These larval morphological characters resemble those described in the other 2 species for which the development in the definitive host is known, Litomoso. sigmodontis (see Scott et al. [1951] and Maréchal et al. [1996]) and Litomosoides legerae (Bain, Petit, and Berteaux, 1980), both parasites of sigmodontine rodents (Bain et al., 1980). The species from bats, however, presents an important difference: the fourth molt occurs when the larvae are much longer than in Litomoso. legerae and Litomoso. sigmodontis (17.8 and $29 \mathrm{~mm}$ long, respectively, in the male and the female, instead of about 5-8 $\mathrm{mm}$ long). This probably signifies a long-lasting fourth-stage development in $\mathrm{Li}$ tomoso. brasiliensis, which is interpreted as a highly derived character. This fits in with its adult characters, such as the arrangement of the male caudal papillae (in tandem on the median line) and the head papillae (reduced number, asymmetry, and joining on the median line of the external labial papillae).

We also noted that during the development of Litomoso. brasiliensis, there was the usual reduction of the alimentary tract with the disappearance of the glandular part of the esophagus. More interesting is the change of position of the vulva: in the last larval stage the vulva is close to the esophageal-intestinal junction, and in the adult the vulva is situated far posterior to the junction. We also observed a similar developmental pathway in Litomoso. sigmodontis. The amplitude of this posterior migration is important because the genital primordium is at the anterior level of the glandular esophagus in the infective stage, as in other members of the family Onchocercidae (Bain and Chabaud, 1986).

\section{Litomosoides chandleri Esslinger, 1973 (Figs. 55-70)}

\section{Material studied}

Four samples from 3 countries and 2 host species. From Venezuela: Agua Fria, Parque Nacional Guatopo, Miranda $\left(10^{\circ} 03^{\prime} \mathrm{N} ; 66^{\circ} 28^{\prime} \mathrm{W}\right)$ $470 \mathrm{~m}$, host Ar. jamaicensis, (0103), 2 March 198, 2 males, 4 females, MNHN 420 SE; from (1379), 28 October 1981, 1 male, 1 female, MNHN 421 SE. From French Guiana: Nouragues $\left(4^{\circ} 05^{\prime} \mathrm{N} ; 52^{\circ} 40^{\prime} \mathrm{W}\right) 85 \mathrm{~m}$, host $\mathrm{Ar}$. jamaicensis, (523), 12 April 1989, 3 males, 1 female, MNHN, 380 SE. From Peru: Pakitza, Parque Nacional Manu, Madre de Dios $\left(11^{\circ} 56^{\prime} \mathrm{S} ; 71^{\circ} 15^{\prime} \mathrm{W}\right) 400 \mathrm{~m}$, host Ar. planirostris (Spix, 1823), (292-100292), 14 February 1992, 1 female, MUSM 1753.

\section{Redescription}

General: Set of head papillae: 4 externo-labial papillae forming a rectangle stretched dorsoventrally and posteriad, 2 large subventral cephalic papillae; amphids at the level of labial papillae. Buccal capsule thick, with 1 more or less conspicuous ring at midlength. Buccal cavity wider in the posterior half or with maximum diameter at midlength. In both sexes the subterminal divergent phasmids are generally thick.

Male: No more than 2 pairs of papillae, generally asymmetrical and reduced to 1-3 papillae. Lamina of left spicule composed of anterior part, 
186 COMPARATIVE PARASITOLOGY, 69(2), JULY 2002
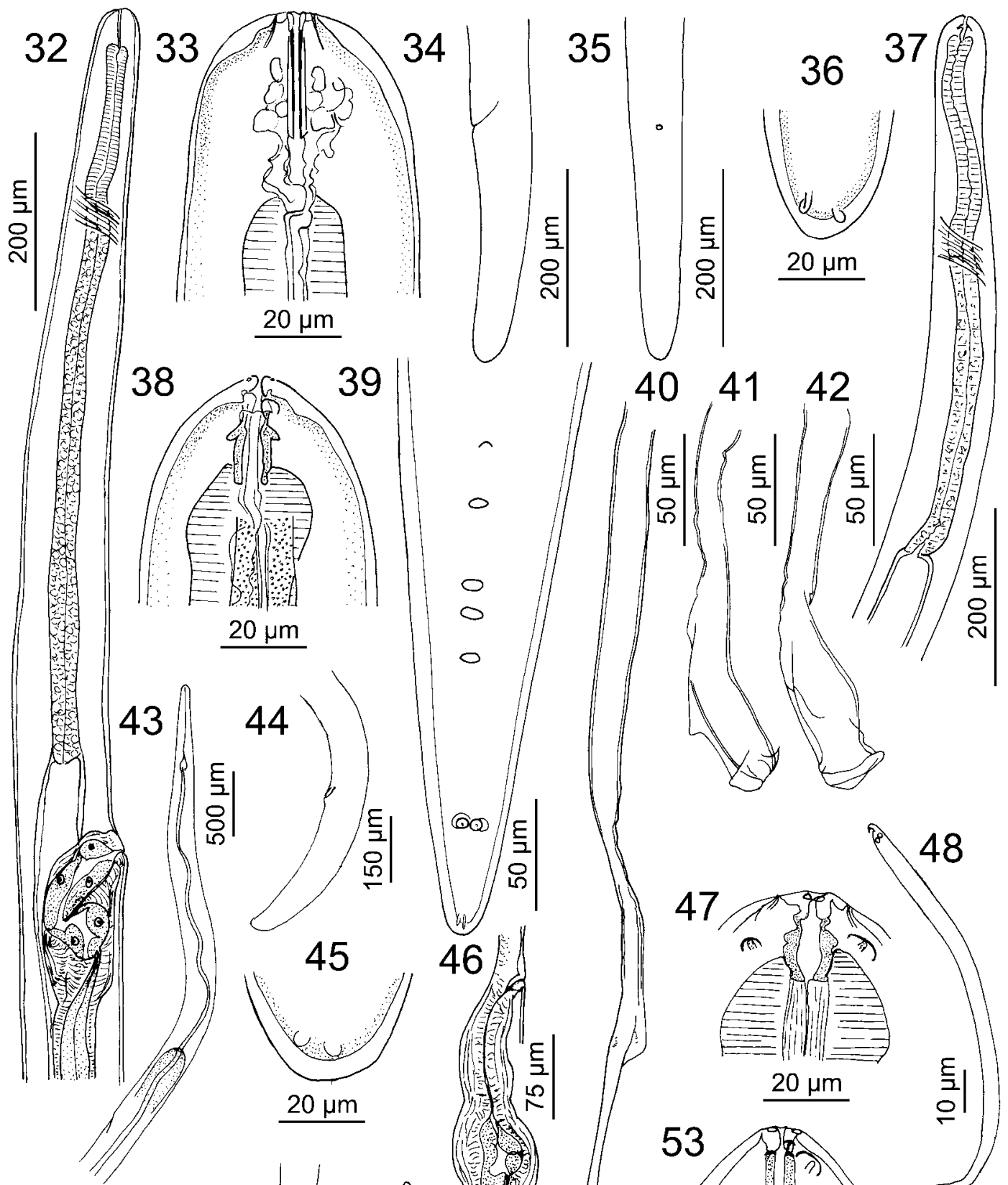

49
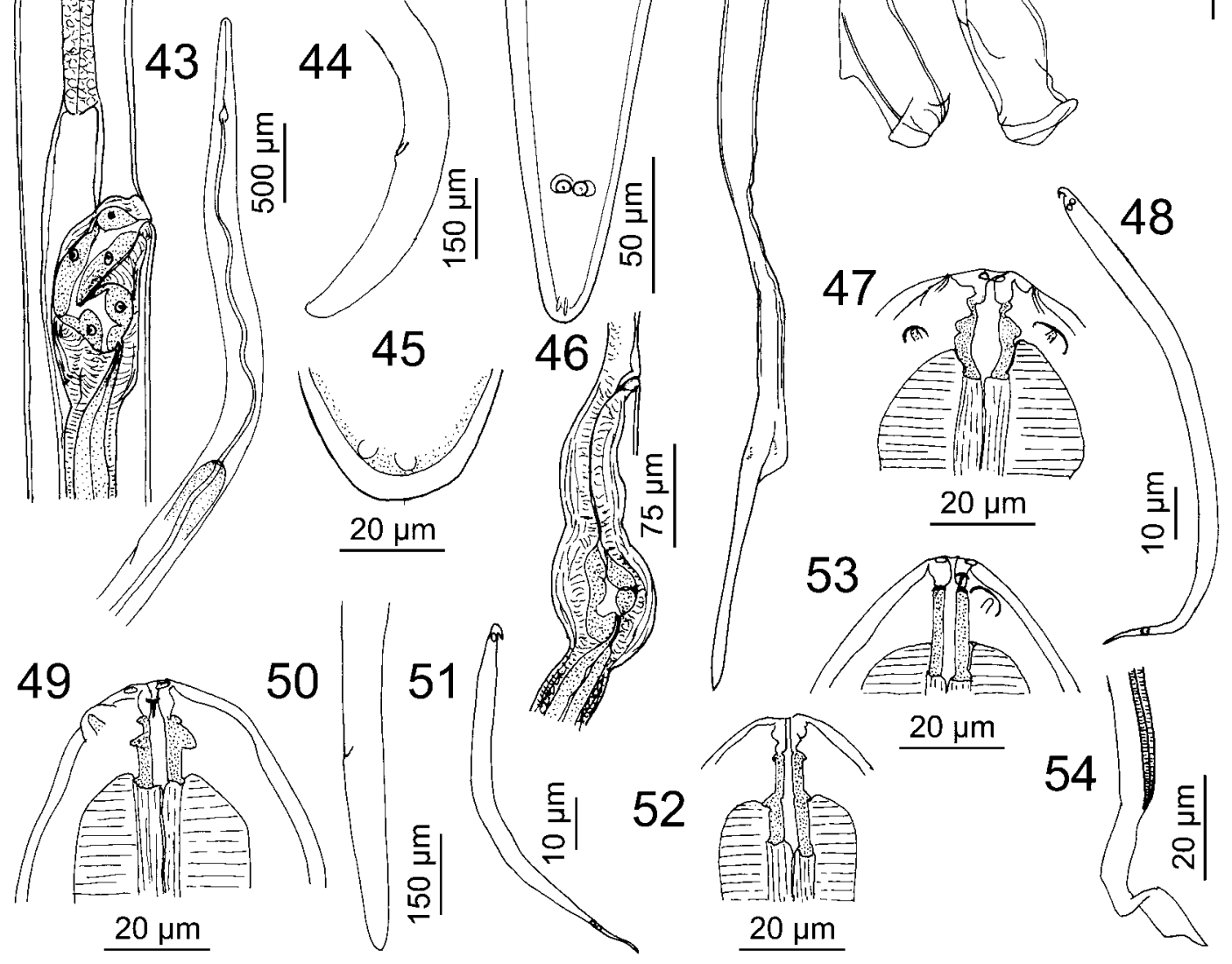
medium part with axis and membranous edge, and of short membranous terminal flap. Right spicule with terminal cap and pronounced heel. Thick testicle beginning at the level of the midesophagus or much farther posterior. Measurements of 2 specimens from $420 \mathrm{SE}$ and 1 specimen from $421 \mathrm{SE}$, from $A r$. jamaicensis are as follows. Length 9.2 (8.6-10.2). Maximum width 110 (85-117); at nerve ring 45 (42-48); at esophageal-intestinal junction 59 (55-66). Buccal capsule 13.7 (12.4-14.4) long, 6.8 (5.6-8) wide; buccal capsule ratio 2.08 (1.7-2.4). Nerve ring 230 (200-280) from apex. Esophagus 480 (450-520) long and $21.5(21-22)$ wide. Tail 100 (90-105) long, width at cloaca $30(28-31)$. Area rugosa from $302-460$ to $1,600-1,608$ and 1,150-1,300 long, transverse ridges $1-1.5$ high, distance between bands $8-12$. Left spicule 215 (190-255) long, handle 117 (145-100) long, and lamina 97 (90-110). Right spicule 62 (56-69) long. Spicular ratio 3.6 (3-4).

Female: Four specimens from $420 \mathrm{SE}$ and 1 specimen from $421 \mathrm{SE}$, from Ar. jamaicensis. Length 22.7 (19.3-24). Maximum width 240 (170-280); at nerve ring 65 (52-96); at esophageal-intestinal junction 105 (90-120); at vulva 115 (100-140). Buccal capsule 15.8 (14.5-16.8) long and 8.2 (7.1-8.8) wide; buccal capsule ratio 1.9 (1.6-2.4). Esophagus 570 (450-690) long and 25 (24-26) wide. Nerve ring 280 (230-320) from anterior end. Vulva $620(540-710)$ to the apex. Vagina $70(60-75)$ long by $55(47-55)$ wide. Tail 230 (195-285) long; width at anus 40 (35-48).

Microfilariae: From Venezuela from Ar. jamaicensis 421 SE: length $60.7 \pm 3$, width 3-3.5 (n = 4); from French Guiana from Ar. jamaicensis 380 SE: length $68.4 \pm 4$, width $3.5-4(n=5)$; from Peru from Ar. planirostris (292-010597): length $52.2 \pm 2.3$, width $3.5-4(n=10)$.

\section{Remarks}

The adult specimens from the 3 collection localities (Venezuela, French Guiana, and Peru) have similar dimensions and morphology. They are identified as Litomoso. chandleri, described from Ar. jamaicensis in Colombia because of the following characters (Esslinger, 1973): small body size, buccal capsule with a ring, bulbous buccal cavity, a lateral row of tiny cuticular bosses in the posterior region of the body, the vulva located at the level of the esophageal-intestinal junction, the tail elongated in the female, the few caudal papillae in the male, and the shapes and sizes of both right and left spicules.

The microfilariae of our material have a cylindrical body, attenuated at the anterior end, with a rounded posterior extremity and a terminal nucleus like those of Litomoso. chandleri. Microfilariae of this species are 58-78 long (mean 69) and 2.4-3.8 (3.1) wide in the original description (Esslinger, 1973), from specimens from Ar. jamaicensis in Colombia. These measurements match the characteristics of the microfilariae from Venezuela and French Guiana parasitic in the same host, but the microfilariae of the single female from a Peruvian specimen of Ar. planirostris, a species closely related to Ar. jamaicensis, are shorter. This sample could represent another closely related species; because no male was recovered, we tentatively consider these specimens to represent Litomoso. chandleri, of which the geographic distribution is extended to Peru and French Guiana. According to Rutkowska (1980), Litomoso. chandleri also occurs in Cuba, where it was recovered from Phyllonycteris poeyi Gundlach, 1860, and from a member of the family Molossidae, $\mathrm{Nyc}$ tinomops laticaudatus (E. Geoffroy, 1805).

Figures 32-54. Litomosoides brasiliensis from Anoura caudifer and Sturnira lilium in Peru. 32-48. Specimens from An. caudifer (CP-MBUC 159-100292). 32-36. Female fourth-stage larva. 32. Anterior region. 33. Head with molting buccal capsule. 34, 35. Tail, lateral and ventral view. 36. Posterior extremity, ventral view. 37-42. Male at the end of the fourth molt. 37. Anterior region. 38. Head, lateral view. 39. Tail, ventral view. 40. Left spicule, ventral view. 41, 42. Right spicule, lateral and dorsal view, respectively. 43-48. Mature female. 43. Anterior region, lateral view. 44. Tail, lateral view. 45. Caudal extremity, ventral view. 46. Vagina, lateral view. 47. Head, ventral view. 48. Microfilaria. 49-54. Specimens from St. lilium (CP-MBUC 86-010597). 49. Female, head, left lateral view. 50. Female, tail lateral view. 51. Microfilaria. 52. Buccal capsule of a male. 53. Buccal capsule of the unique male without ring. 54. Distal extremity of the left spicule. 
55

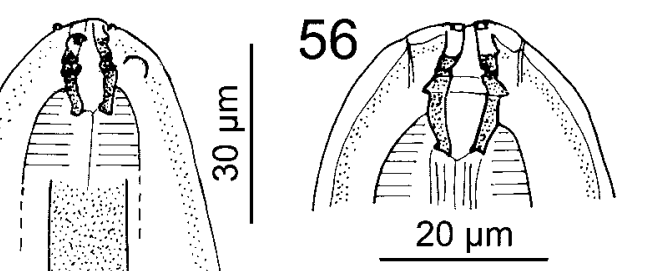

57

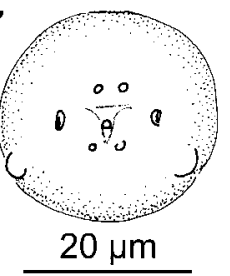

58
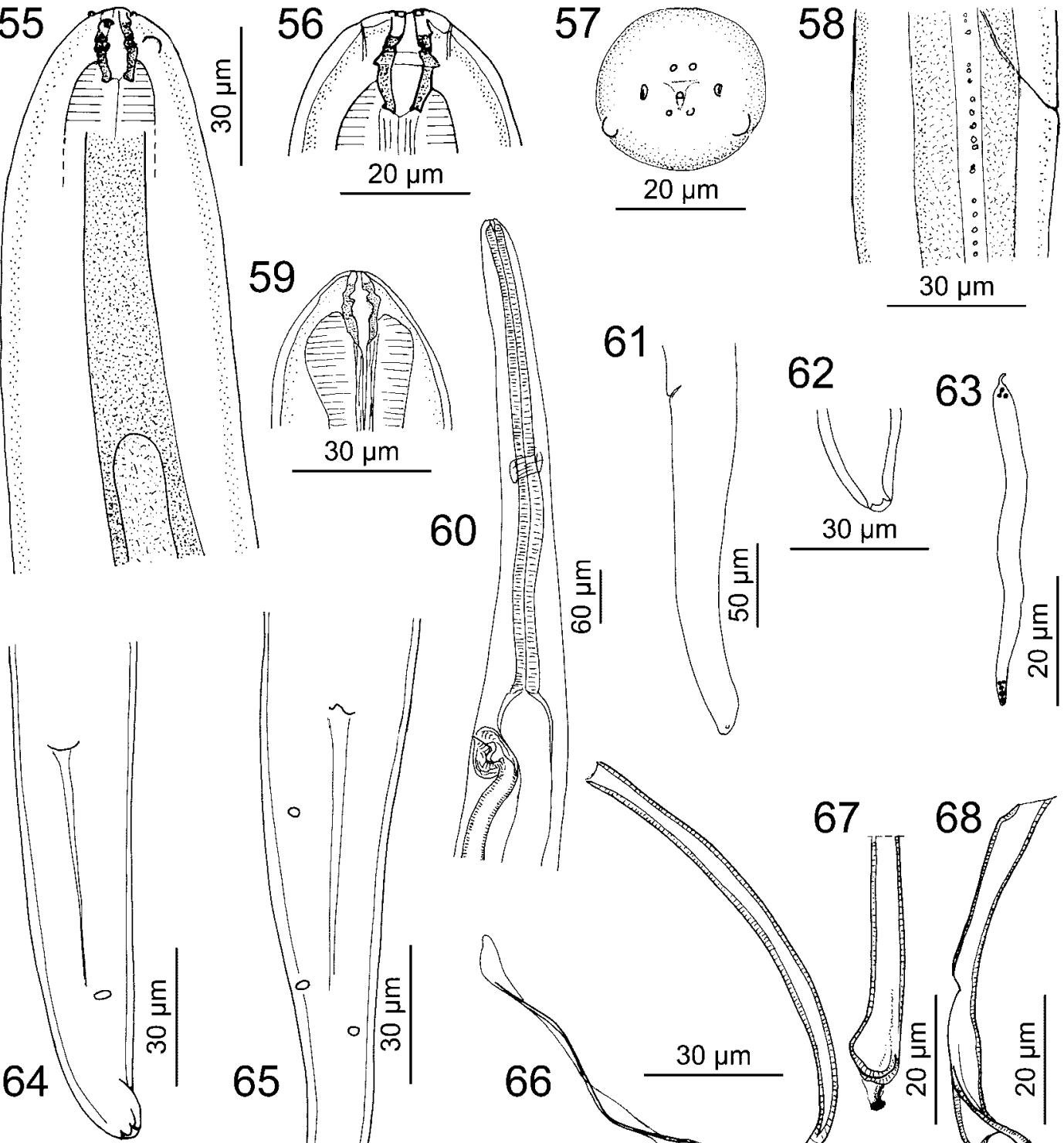

65
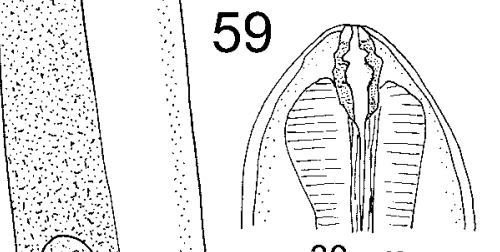

$(5)$

(3)
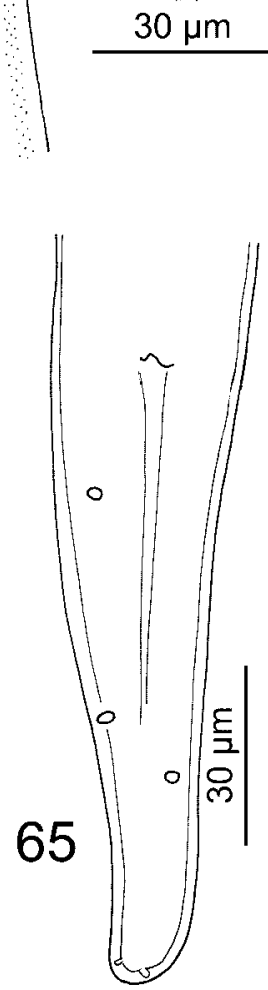

69

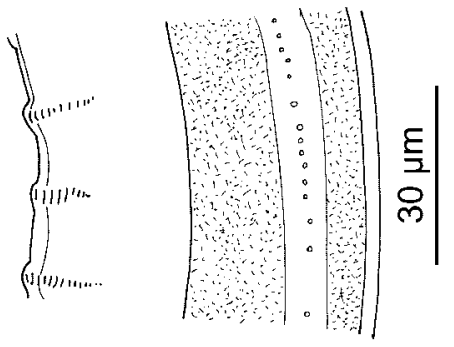

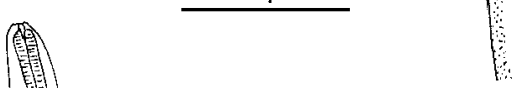

$30 \mu \mathrm{m}$

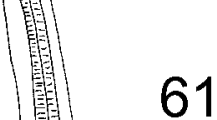

61
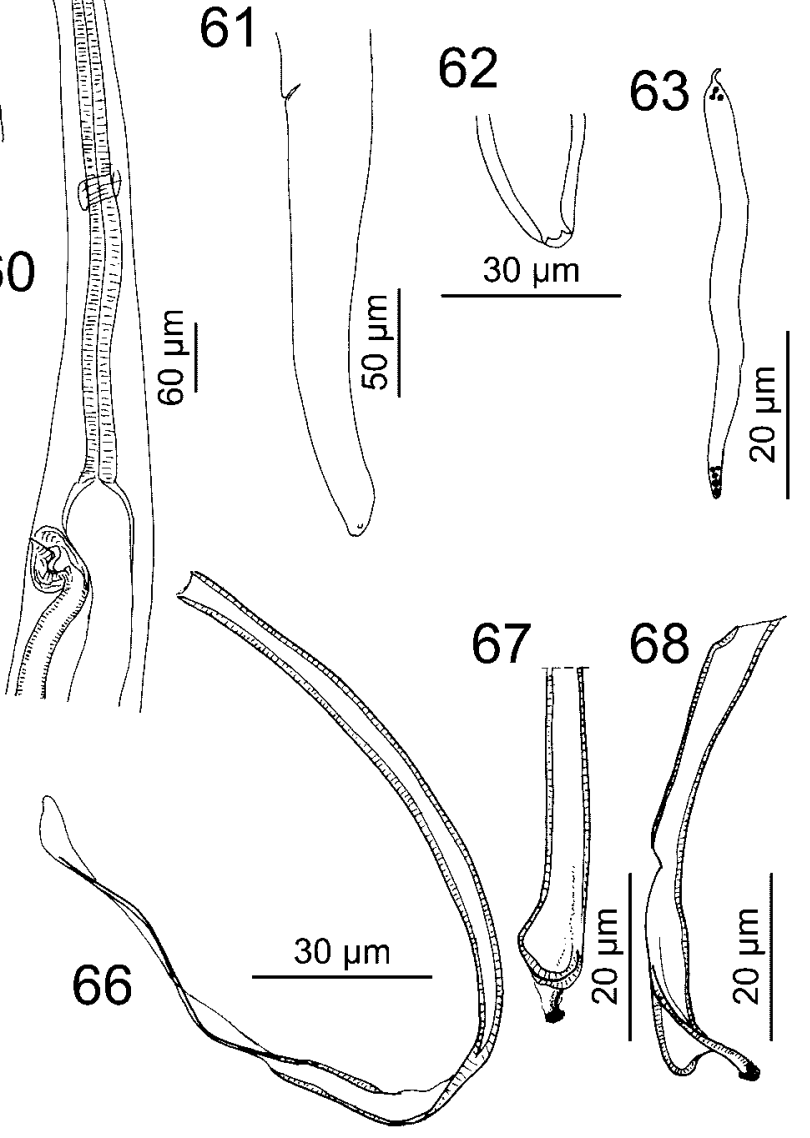

70

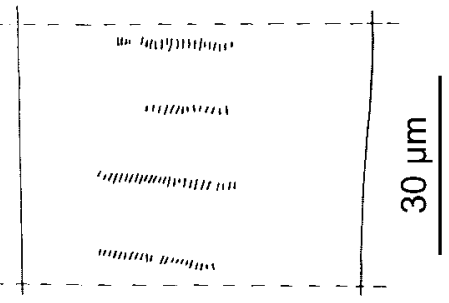




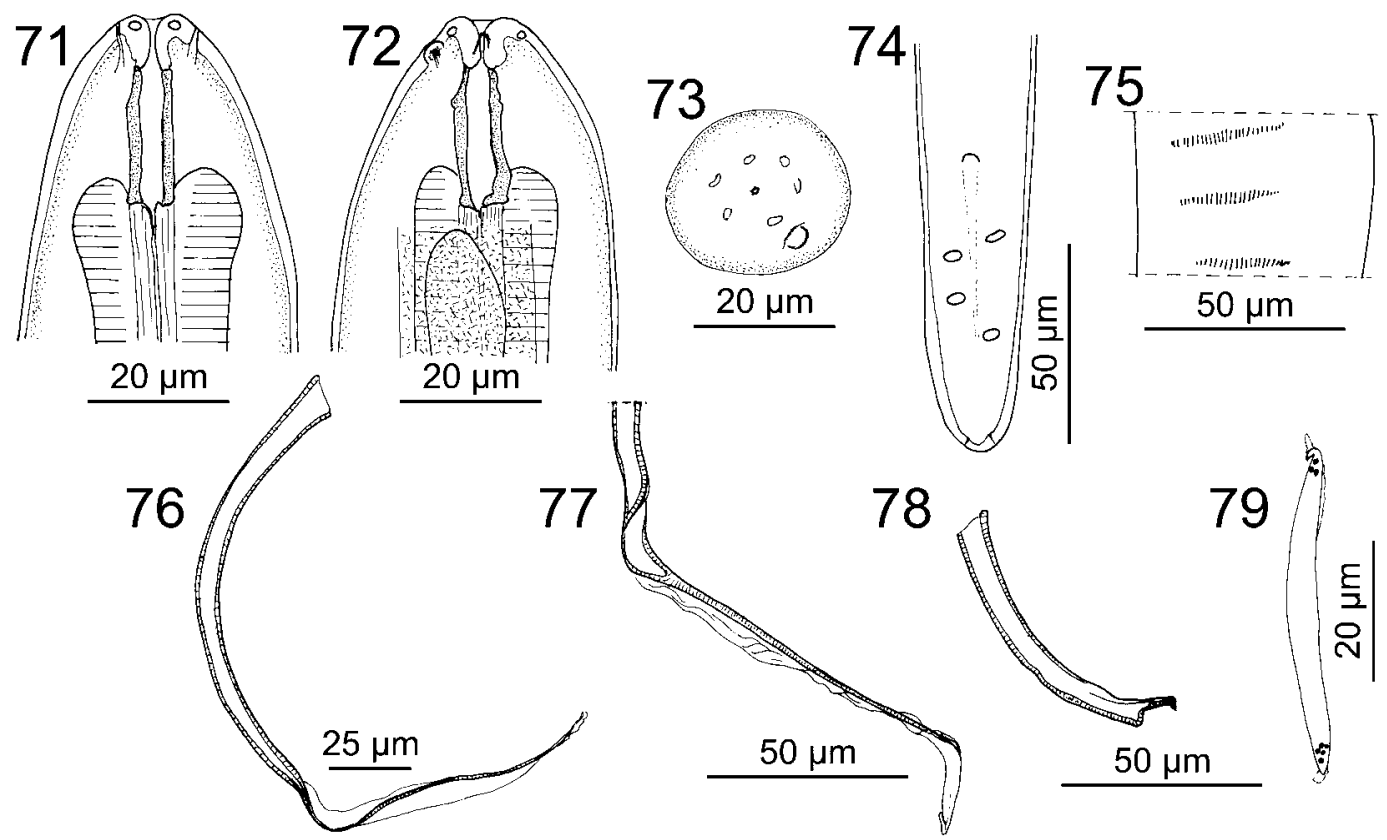

Figures 71-79. Litomosoides guiterasi from Glossophaga soricina in Venezuela (MNHN 419 SE). 71-73. Female, head, dorsal, left lateral, and apical views, respectively. 74-77. Male. 74. Tail, ventral view. 75. Area rugosa, ventral view. 76. Left spicule, lateral view. 77. Lamina of left spicule. 78. Right spicule. 79. Microfilaria.

\section{Litomosoides guiterasi (Pérez, 1934)}

(Figs. 71-79)

\section{Material studied}

Venezuela, Agua Fria, Parque Nacional Guatopo, Miranda $\left(10^{\circ} 03^{\prime} \mathrm{N} ; 66^{\circ} 28^{\prime} \mathrm{W}\right) 470 \mathrm{~m}$, host Gl. soricina (1472), 25 November 1981, 3 males, 2 females, MNHN 418 SE; from (1484), same date, 14 males, 5 females, 10 anterior and 4 posterior regions of females, MNHN 419 SE.

\section{Redescription}

General: Set of head papillae: 4 externo-labial papillae arranged in a rectangle slightly stretched dorso-ventrally, and posteriad, single large subventral cephalic papilla; amphids at the level of labial papillae rarely salient, sometimes slightly dorsal in position. Buccal cavity long and narrow, thin and cylindrical, slightly attenuated anteriorly, with 1 tiny anterior ring. Esophagus with or without well-defined glandular part.

Male: Tail with 2 pairs of postcloacal papillae situated slightly asymmetrically in 2 ventrolateral lines; sometimes, third pair present but reduced to 1 papilla; tiny subterminal phasmids. Lamina of left spicule composed of well-cuticularized axis with membranous edges, and membranous terminal flap. Right spicule with sclerotized distal part, rearing subterminal dorsal hook, and dorsal heel. Thick testicle, beginning at the level of the nerve ring or far behind the esophagus. Measurements (3 specimens from $418 \mathrm{SE}$ and 3 from $419 \mathrm{SE}$ ) are as follows.

Figures 55-70. Litomosoides chandleri from Artibeus jamaicensis in Venezuela and Ar. planirostris in Peru. 55-58. Female from Ar. jamaicensis (MNHN $420 \mathrm{SE}$ ). 55. Anterior region, right lateral view. 56, 57. Head, dorsal and apical views, respectively. 58. Lateral cuticular ornamentation. 59-63. Female from Ar. planirostris (MUSM 1753). 59. Buccal capsule. 60. Anterior region, lateral view. 61. Tail, lateral view. 62. Posterior extremity, ventral view. 63. Microfilaria. 64-70. Male from Ar. jamaicensis (MNHN 420 SE). 64, 65. Two tails, ventral view. 66. Left spicule, lateral view. 67, 68. Right spicule, dorsal and lateral view, respectively. 69. Lateral cuticular ornamentation. 70. Area rugosa, at midlength, ventral view. 
Length 14.9 (13.4-16.0) and 16.1 (13.6-17.6) $\mathrm{mm}$. Maximum width $104(98-112)$ and 108 (100-115); at nerve ring 46 (44-48); at esophageal-intestinal junction 66 (66-72). Buccal capsule 19 (19-20) and 23.6 (22-26) long, 7 (7$7.5)$ and 6.3 (6-7) wide; buccal capsule ratio 2.6-2.7. Nerve ring 219 (174-264) from apex. Esophagus 598 (558-656) and 528 (450-625) long and 23.3 (20-25) wide. Tail 64 (61-67) and 59 (48-68) long, width at cloaca 31 (29-34). Area rugosa from 390 to $1,870(1,480)$ and 400 to $1,500(1,800)$, transversal ridges 2.5 and 2 high, interridges 9-12 and 5-8. Left spicule 209 (200-218) and 213 (195-245) long, handle 120 (116-122) and 128 (120-135) long. Right spicule 77 (71-84) and 79 (75-85) long. Spicular ratio $2.75(2.73-2.82)$ and $2.70(2.35-3.14)$.

Female: (Mean of 2 specimens $418 \mathrm{SE}$ and of 2 specimens 419 SE.) Length 40.3 and $51.3 \mathrm{~mm}$. Maximum width 162 and 180; at nerve ring 57 and 58; at esophageal-intestinal junction 84 and 89 ; at vulva 81 and 88 . Buccal capsule 23 and 28.5 long, 5.7 and 5.8 wide; buccal capsule ratio 4.0 and 4.5. Esophagus 600 and 700 long, 25 and 26 wide. Nerve ring 225 and 195 from anterior end. Vulva 509.5 and 507.5 from apex. Vagina spherical, 56 and 54 long by 45 and 43 wide. Tail 134.5 and 135 long, cylindrical with rounded end; width at anus 56 and 50. Thin phasmids, almost joined at their bases or parallel; no salient notch at extremity.

Microfilariae: (From 3 females 419 SE.) Both extremities attenuated, posterior end often flexed, its extremity rather sharp. Sheath slightly longer than body. Length $47.8 \pm 1.1(n=5)$, $50.3 \pm 2.1(n=13), 54 \pm 2.5(n=11)$, respectively. Total mean $51.5 \pm 3.4$; width $2.5-$ 4.5 .

\section{Remarks}

Litomosoides guiterasi (Pérez, 1934) has been described from Ar. jamaicensis parvipes from Cuba and then redescribed by Rego (1961) and Esslinger (1973) from Gl. soricina in Brazil and Colombia, respectively. Some discrepancies exist among these descriptions in that the type specimens are shorter, and the buccal cavity is not drawn as a narrow tube (Pérez, 1934; Fig. 2). Our specimens from Gl. soricina in Venezuela are similar to those described from the same host. The dimensions of the adults are similar, the buccal cavity is long and narrow with thin walls and a tiny anterior ring, the tail is short and slightly attenuated, the caudal papillae are reduced to only 2 or 3 pairs, the vulva is at the level of the esophagus, and the vagina is small and spherical. Up to the present, the microfilaria of Litomoso. guiterasi has been described only from Colombia in stained blood smears by Esslinger (1973). Microfilariae of our material are also small and are attenuated at both extremities; however, the body is generally less fusiform, and the posterior extremity is often flexed.

\section{Litomosoides solarii sp. $\mathbf{n}$. (Figs. 80-86)}

\section{Description}

Buccal capsule markedly longer than broad, walls straight, with slight ring at midlength; buccal cavity cylindrical (mouth of the only specimen artificially invaginated). Vulva anterior to esophageal-intestinal junction, vagina elongated. Tail thin, attenuated, with round bent end, phasmids divergent.

Female (holotype): Length 52.9. Maximum width 150 , width at nerve ring 81 , at esophageal-intestinal junction 96, at vulva 98. Buccal capsule 21 long and 7 wide, ratio of length to width 3.0. Esophagus 935 long and 26 wide. Nerve ring 290 from anterior end. Vulva 910 to apex. Vagina 105 long by 40 wide. Tail 250 long, width at anus 48 .

Microfilariae: Body almost cylindrical, with posterior extremity abruptly attenuated to a sharp point. Measurements (9 specimens): length $53.7 \pm 3.5$, width $3.8-4.3$.

\section{Taxonomic summary}

Type host: Trachops cirrhosus (Spix, 1823) (fringe-lipped bat) (Chiroptera: Phyllostomidae).

Type locality/collection date: Pakitza, Manu Na-

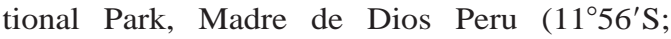
$\left.71^{\circ} 15^{\prime} \mathrm{W}\right) 400 \mathrm{~m}$, field number (09-100292), 14 February 1992.

Infection site: Body cavity.

Prevalence and intensity of infection: 1/1.

Specimens deposited: Female holotype, MUSM 1738.

Etymology: Named after Sergio Solari, who collected and identified the host and many other bats. 


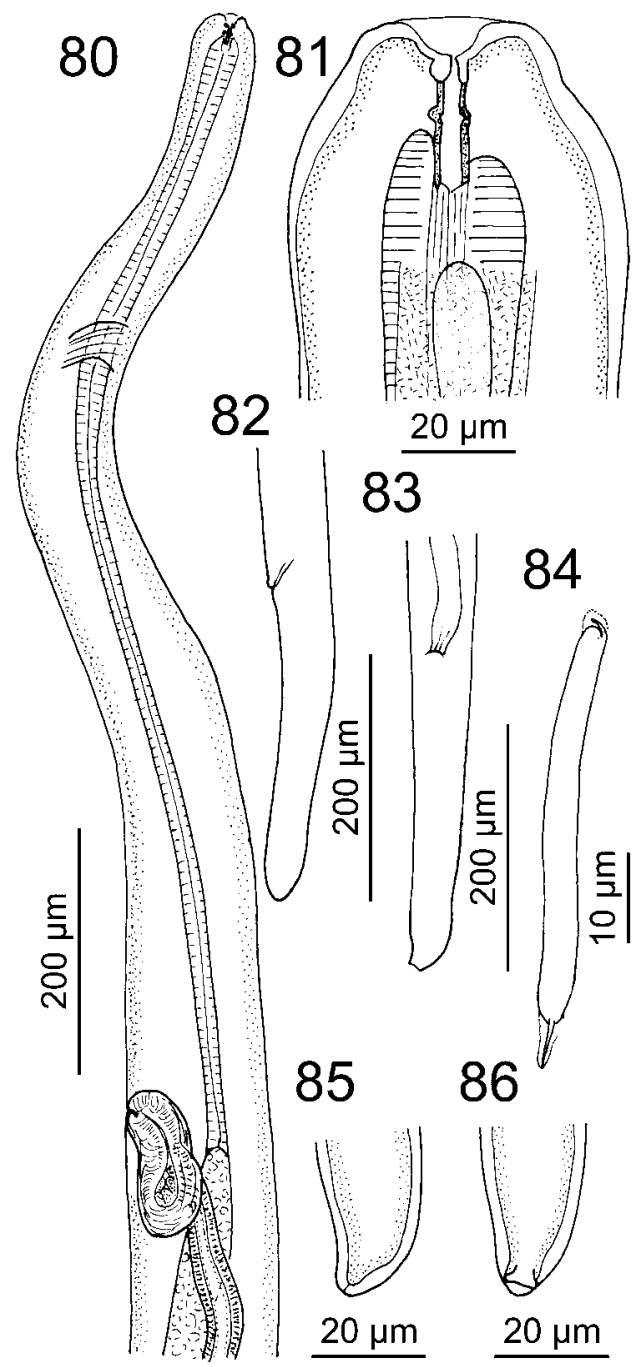

Figures 80-86. Litomosoides solarii sp. n. from Trachops cirrhosus in Peru. 80. Holotype (MUSM 1738), anterior region. 81. Head. 82, 83. Tail, lateral and ventral view, respectively. 84. Microfilaria. 85, 86. Posterior extremity, lateral and ventral view, respectively.

\section{Remarks}

The female of Litomoso. solarii most closely resembles that of Litomoso. guiterasi, having a similar body size, a long narrow buccal cavity with thin walls, and the vulva in the region of the esophagus. However, the tail is longer and thinner, and the microfilariae are different, having a unique shape. This feature of the microfilariae serves to separate Litomoso. solarii from all other species of Litomosoides from which the microfilariae are known (see Mazza [1928], Esslinger [1973], Muller [1980], Bain et al. [1980, 1989], Gardner and Schmidt [1986], Brant and Gardner [1997], Moraes-Neto et al. [1996, 1997], Notarnicola et al. [2000], and the present study).

Among those species for which the microfilariae are unknown, Litomoso. solarii can be distinguished as follows. The Litomosoides sp. of Chitwood (1938), from bats, has a shorter and wider buccal cavity, a longer tail, and a postesophageal vulva; Litomosoides hamletti Sandground, 1934, from Gl. soricina in Brazil (Mato Grosso), has a short and robust tail (ratio 1.8 compared with 5.2); Litomosoides leonilavazquezae Caballero, 1939, from Macrotus waterhousii (Gray, 1843) in Mexico, has a shorter buccal capsule (16 long) with a thick wall, and a vulva very distant from the esophageal-intestinal junction, as in Litomosoides fosteri Caballero, 1947, described from Gl. soricina; in addition, this last species has a buccal capsule with 2 rings. Litomosoides circularis (Linstow, 1899), from rodents, has a wider buccal cavity and a tail 3 times longer than that of Litomoso. solarii.

Until now, no Litomosoides species had been recorded from any Trachops species.

\section{Litomosa westi}

(Gardner and Schmidt, 1986) comb. n. Litomosa thomomydis

(Gardner and Schmidt, 1986) comb. n. (Figs. 87-93)

\section{Material studied}

Litomosa westi: Three males and 1 female from Geomys bursarius (Shaw, 1800), MNHN 10 HS. Litomosa thomomydis: 1 male and 1 female, MNHN 11 HS; 1 male and 1 female, MNHN 4 HS; 1 male, MNHN 9 HS, all from Thomomys talpoides (Richardson, 1828). The host specimens were collected in Colorado, U.S.A., mainly by Wilson in 1960, and deposited by S.L.G. in the MNHN, Paris.

\section{Redescription}

General: Posterior part of buccal capsule embedded in esophagus. Organization of area rugosa as in other congeners. Microfilariae with body regularly widening from posterior extremity to anterior part and folded inside the shorter sheath; cephalic hook very small and not protruding on apex. Other characters follow the original descriptions of Gardner and Schmidt 

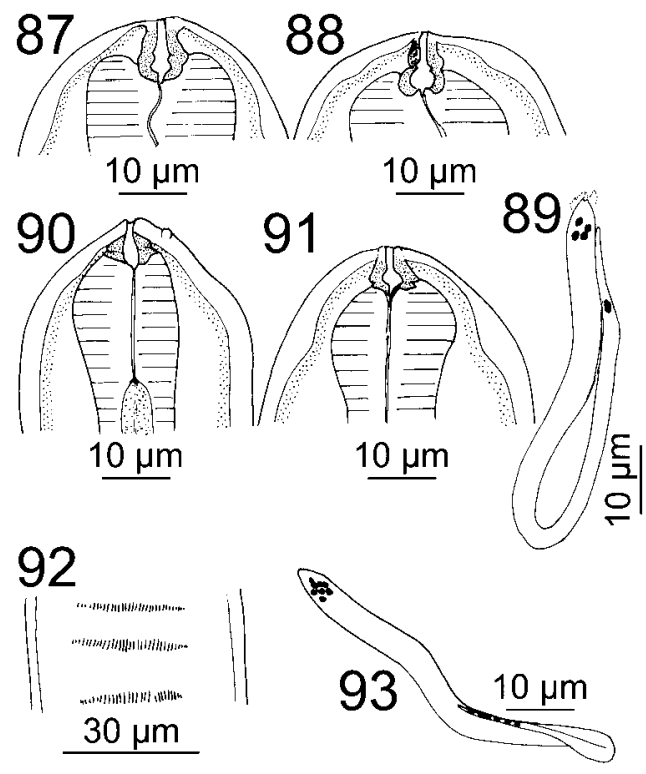

Figures 87-93. Litomosa westi and Litomosa thomomydis from Geomyidae. 87-89. Female of $\mathrm{Li}$ tomosa westi (MNHN $10 \mathrm{HS}) .87, \mathbf{8 8}$. Buccal capsule, median and lateral view, respectively. 89. Microfilaria. 90-92. Litomosa thomomydis (MNHN 11 HS). 90. Buccal capsule of male, lateral view. 91. Buccal capsule of female, median view. 92. Area rugosa, ventral view. 93. Microfilaria.

(1986); general measurements of females and males are according to these authors.

Male: Area rugosa from $735-805$ to 2,9253,395 (2,120-2,660 long), transverse ridges 2-4 high, distance between bands 11-15 in Litomosa westi, and area rugosa from 450-530 to 2,2602,300 (1,810-1,770 long), transverse ridges 2, distance between bands 10 in Litomosa thomomydis.

Microfilariae: Those of Litomosa westi 105106 long, 3.5-4 wide; those of Litomosa thomomydis 87-98 long, 4-4.5 wide.

\section{Remarks}

Both Litomosa westi and Litomosa thomomydis have extremely derived characters, illustrated by the reduction of the head and caudal sensory organs, thus their generic position is difficult to establish. The small buccal cavity of these 2 species appeared unique among Litomosoides species. The new feature observed was that their microfilariae have a unique shape. In general, the first larval stage of filarioid nematodes can- not be used to define a genus. However, in species of Litomosoides, microfilariae have a shape that is easy to recognize, with a relatively voluminous and salient cephalic hook, and a straight body attenuated at both extremities inside a longer sheath. Thus, the particular morphology of the microfilariae in the 2 species from Geomyidae is an important character, which when added to the peculiarities of the adults (spicules, vagina, caudal lappets, as emphasized by Gardner and Schmidt [1986] and Bain et al. [1989]), does not permit their retention in the genus Litomosoides.

The microfilariae of Litomosa westi and Litomosa thomomydis, in contrast, closely match those of 2 other genera, Josefilaria Moorhouse, Bain, and Wolf, 1979 and Litomosa Yorke et Maplestone, 1926, both parasites of Old World bats. They have a very minute hook, a body tapering from the head to the posterior extremity, and the posterior third of the body reflected back in a shorter sheath (Moorhouse et al., 1979; Tibayrenc et al., 1979; Petit, 1980). This last character is not a sign of nonmaturation because it is maintained when microfilariae are recovered from subcutaneous tissue (Moorhouse et al., 1979 ) or the host's blood (Bain, personal observation of Litomosa filaria van Beneden, 1870).

However, Josefilaria mackerrasae Moorhouse, Bain, and Wolf, 1979, the only species in the genus, differs from the parasites of geomyids because the buccal capsule is not embedded posteriorly in the esophagus. In contrast, species of Litomosa have a thick buccal capsule partially embedded in the esophagus, very similar to that in both Litomosa westi and Litomosa thomomydis.

The resemblance of Litomosa westi and Litomosa thomomydis to some Litomosa spp. has been noted before (Bain et al., 1989), e.g., the elongated vagina constricted at midlength, the tiny buccal cavity widening posteriorly, and the right spicule without a heel and widening at midlength (as in Litomosa maki Tibayrenc, Bain, and Ramachandran, 1979, and Litomosa aelleni Tibayrenc, Bain, and Ramachandran, 1979), the caudal papillae grouped near the cloaca (as in Litomosa aelleni) and in Litomosa westi, the well-developed caudal lappets (as in Litomosa vaucheri Petit, 1980). The area rugosa, composed of transverse ridges of longitudinal crests, is also found in some species of Litomosa, such as Litomosa dogieli Bogdanov and Vladimirov, 
1956, (=Litomosa desportesi Bain, 1966), although generally in this genus, the area rugosa comprises irregularly distributed cuticular bosses (Bain, 1966; Petit, 1980). Consequently, the 2 species parasitic in the Geomyidae are hereby transferred to the genus Litomosa.

A parasite of the caviomorph rodent Ctenomys opimus Wagner, 1848, in Bolivia, Litomoso. andersoni Brant and Gardner, 1997, has been placed in the original description close to Litomosa westi and Litomosa thomomydis, but the morphological data available are not convincing. The variation of the length of the left spicule is unusually great ( 286 to $654 \mu \mathrm{m}$ ), the buccal capsule is shown either embedded in the esophagus or not, and these 2 features suggest a conflation of species in the description of Brant and Gardner (1997). The very short buccal capsule (4-7 in the female) and the right spicule with a distal triangular complex region resemble those found in species included in the genus Ackertia (cf. Bain and Hocquet, 1968), which is a common parasite of caviomorph rodents. In addition, the microfilariae resemble those of Litomosoides ctenomyos Brant and Gardner, 1997. Additional material would help to solve the taxonomic questions.

\section{DISCUSSION}

This examination of 3 known species of $\mathrm{Li}$ tomosoides from bats, Litomoso. brasiliensis, $\mathrm{Li}$ tomoso. chandleri, and Litomoso. guiterasi, confirms that the carinii group occurs in bats. It remains to determine whether those species from bats placed in the sigmodontis group also fit into its definition or constitute another distinct group in these hosts. This second hypothesis seems unlikely because our study provides new data supporting the arguments for the similarities between the Litomosoides species of bats, marsupials, and rodents. The plane of organization of the head papillae is very constant in the genus: the external labial papillae are placed on a rectangle stretched medially and the cephalic ones on a rectangle stretched laterally (Bain et al., 1980, 1989; Moraes-Neto et al., 1996, 1997; Notarnicola et al., 2000). In addition, the same evolutionary trends of the sensory system are noted in all host groups: the disappearance of 2 cephalic papillae, very likely the dorsal ones, and the migration toward the median line of the labial papillae, which may fuse. Similarly a mi- gration of the caudal papillae toward the median line is observed.

The hypothesis of captures is thus reinforced. However, it is no longer possible to consider that bats are the ancestral hosts, as first suggested (Bain et al., 1980; Bain and Philipp, 1991), because the adult and larval characters of these Litomosoides species are not particularly primitive. The diversification of Litomosoides in the diverse groups of terrestrial and flying mammals seems to have occurred simultaneously and recently. A very similar conclusion was drawn with the cladistic analysis of Brant and Gardner (2000). No life cycle of bat filariae is known. The Macronyssidae mites transmit species from rodents as well as from marsupials, at least experimentally. These mites have a large distribution and host range (Micherdzinski, 1980) and they might be at the root of the host-switching, which has been unusually common in this group.

The 2 parasites of the Nearctic subterranean Geomyidae appear more closely related to $\mathrm{Li}$ tomosa in which they are transferred. However, the 2 genera Litomosoides and Litomosa have in common some particular morphological features, such as the strongly cuticularized buccal capsule posteriorly embedded in the esophagus, and only the microfilarial morphology distinguishes them clearly. The phylogenetic origin of Litomosoides remains unknown, but it appears difficult to dissociate its history from that of $\mathrm{Li}$ tomosa.

\section{ACKNOWLEDGMENTS}

Thanks are extended to Jesús Gómez, who collected many of the Venezuelan samples, Don E. Wilson and F. Dallmeier from Smithsonian Institution, Washington, D.C., who provided facilities to collect the Peruvian material, Prof. André Brosset, who collected and identified the bats from French Guiana, Nicole Jouvenet, who recovered the filarial worms from the Guianese bats, and Dr. Helmut Sattmann in the Naturhistoriches Museum Wien, who afforded access to Molin's specimens. The study was partially financed by the Consejo de Desarrollo Cientifico y Humanistico $(\mathrm{CDCH})$ of the Universidad Central de Venezuela, the Consejo Nacional de Investigaciones Cientificas y Tecnologicas $(\mathrm{CON}-$ ICIT), and the Centre National de la Rechercehe Scientifique (CNRS) project PI-9900023O. We thank Dr. John Baker for his valuable comments. 


\section{LITERATURE CITED}

Allen, J. E., J. Daub, D. Guiliano, A. McDonnell, M. Lizotte-Waniewski, D. W. Taylor, and M. Blaxter. 2000. Analysis of genes expressed at the infective larval stage validates utility of Litomosoides sigmodontis as a murine model for vaccine development. Infection and Immunity 68:54545458.

Bain, O. 1966. Diversité et étroite spécificité parasitaire des Filaires de chauves-souris, confondues sous le nom de Litomosa filaria (van Beneden, 1972). Bulletin du Muséum National d'Histoire Naturelle, Paris, 2e Série 38:928-939.

Bain, O., and A. G. Chabaud. 1986. Atlas des larves infestantes de Filaires. Tropical Medicine and Parasitology 37:237-340.

Bain, O., and P. Hocquet. 1968. Ackertia dorsti n. sp., parasite de la viscache Lagidium peruanum. Bulletin du Muséum National d'Histoire Naturelle, Paris, 2e Série 40:399-402.

Bain, O., G. Petit, and S. Berteaux. 1980. Description de deux nouvelles Filaires du genre Litomosoides et de leurs stades infestants. Annales de Parasitologie Humaine et Comparée 55:225-237.

Bain, O., G. Petit, and M. Diagne. 1989. Etude de quelques Litomosoides parasites de rongeurs; conséquences taxonomiques. Annales de Parasitologie Humaine et Comparée 64:268-289.

Bain, O., and M. Philipp. 1991. Modèles animaux utiles pour l'étude des phénomènes parasitaires: filaires et autres parasites. Annales de Parasitologie Humaine et Comparée 66(supplement 1):6468.

Brant, S. V., and S. L. Gardner. 1997. Two new species of Litomosoides (Nematoda: Onchocercidae) from Ctenomys opimus (Rodentia: Ctenomyidae) on the Altiplano of Bolivia. Journal of Parasitology 83:700-705.

Brant, S. V., and S. L. Gardner. 2000. Phylogeny of species of the genus Litomosoides (Nematoda: Onchocercidae): evidence of rampant host switching. Journal of Parasitology 86:545-554.

Brosset, A., P. Charles-Dominique, A. Cockle, J. F. Cosson, and D. Masson. 1996. Bat communities and deforestation in French Guiana. Canadian Journal of Zoology 74:1974-1982.

Caballero, E. 1944. Una nueva especie del género $\mathrm{Li}$ tomosoides y consideraciones acerca de los caracteres sistemàticos de las especies de este género. Anales del Instituto de Biologia 15:383-388.

Chabaud, A. G. 1982. Spectre d'hôtes et évolution des Nématodes parasites de Vertébrés. 2e Symposium sur la Spécificité Parasitaire des Parasites de Vertébrés, 13-17 April 1981. Mémoires du Muséum National d'Histoire Naturelle, Série A, Zoologie 123:73-76.

Chitwood, B. G. 1938. Some Nematodes from the caves of Yucatan. Carnagie Institution of Washington 491:51-66.

Dallmeier, F., and A. Alonso, eds. 1997. Biodiversity assessment and monitoring of the Lower Urubamba Region, Peru. 1. San Martin-3 and Cashiriari-2 well sites. Smithsonian Institution Monitoring \&
Assessment of Biodiversity Program (SI/MAB), Series 1. 368 pp.

Diaz-Ungria, C. 1963. Nématodes parasites, nouveaux ou intéressants du Vénézuéla. Annales de Parasitologie Humaine et Comparée 38:893-914.

Esslinger, H. 1973. The genus Litomosoides Chandler, 1931 (Filarioidea: Onchocercidae) in Colombian bats and rats. Journal of Parasitology 59:225-246.

Gardner, S. L., and G. Schmidt. 1986. Two new species of Litomosoides (Nematoda: Onchocercidae) from pocket gophers (Rodentia: Geomyidae) in Colorado. Systematic Parasitology 8:235-242.

Guerrero, R. 1993. Catalogo de los Streblidae (Diptera: Pupipara) parasitos de murcielagos (Mammalia: Chiroptera) del Nuevo Mundo. I. Clave para los géneros y Nycterophiliinae. Acta Biologica Venezuelica 14:61-76.

Lins de Almeida, J. 1936. Sobre um parasito de "cheiroptera": Litosomoides brasiliensis Lins de Almeida, 1936 (Nematoda-Filariidae). Revista do Departamento National da Producçao Animal 3: 133-135.

Maréchal, P., L. Le Goff, G. Petit, M. Diagne, D. W. Taylor, and O. Bain. 1996. The fate of the filaria Litomosoides sigmodontis in susceptible and naturally resistant mice. Parasite 3:25-31.

Marshall, L. G. 1979. A model for paleobiogeography of South American cricetine rodents. Paleobiology 5:26-132.

Martin, C., K. M. Al Qaoud, M. N. Ungeheuer, K. Paehle, P. N. Vuong, O. Bain, B. Fleicher, and A. Hoerauf. 2000. IL-5 is essential for vaccine induced protection and for resolution of primary infection in murine filariasis. Medical Microbiology and Immunology 189:67-74.

Mazza, S. 1928. Filarideo n. sp. de la cavidad peritoneal de la rata de los canaverales de Tabacal, Salta. Reunion de la Sociedad Argentina de Parasitologia Regional del Norte 4:628-632.

Micherdzinski, W. 1980. Eine Taxonomische Analyse der Familie Macronyssidae Oudemans, 1936. I. Subfamilie Ornithonyssinae Lange, 1958 (Acarina, Mesostigmata). Panstwowe Wydawnictwo Naukow, Warsaw, Poland. 264 pp.

Molin, R. 1858. Versuch einer Monographie der Filarien. Sitzungsberichte der Kaiserlichen Akademie der Wissenschaften 28:365-461.

Moorhouse, D. E., O. Bain, and G. Wolf. 1979. Josefilaria mackerrasae gen. et sp. nov. (Nematoda: Filarioidea) parasite de la chauve-souris Macroderma gigas Dodson. Annales de Parasitologie Humaine et Comparée 54:645-651.

Moraes Neto, A. H. A. de, R. M. Lanfredi, and W. de Souza. 1996. Emended description of Litomosoides silvai (Nematoda: Filarioidea) of Akodon cursor (Rodentia: Muridae). Journal of Parasitology 82:988-991.

Moraes Neto, A. H. A. de, R. M. Lanfredi, and W. De Souza. 1997. Litomosoides chagasfilhoi sp. nov. (Nematoda: Filarioidea) parasitizing the abdominal cavity of Akodon cursor (Winge, 1887) (Rodentia: Muridae) from Brasil. Parasitological Research 83:137-143.

Muller, R. 1980. Litomosoides barretti n. sp. from the 
ashy oposum in Brazil (Nematoda: Filarioidea). Revista Basileira de Biologia 40:81-83.

Notarnicola, J., O. Bain, and G. T. Navone. 2000. Two new species of Litomosoides (Nematoda: Filarioidea) in sigmodontines (Rodentia: Muridae) from Rio de la Plata marshland and Parana delta, Argentina. Journal of Parasitology 86:1318-1325.

Pérez, V. I. 1934. Notas sobre las especies de Filaroidea encontradas en Cuba. Memorias de la Sociedad Cubana de Historia Natural "Felipe Poey" 8:55-60.

Petit, G. 1980. Sur les filaires du genre Litomosa (Nematoda: Filarioidea), parasites de chauvessouris. Bulletin du Muséum National d'Histoire Naturelle, Paris, 4e Série 2:365-374.

Petit, G., M. Diagne, P. Maréchal, D. Owen, D. W. Taylor, and O. Bain. 1992. Maturation of the filaria Litomosoides sigmodontis in BALB/c mice; comparative susceptibility of nine other inbred strains. Annales de Parasitologie Humaine et Comparée 67:144-150.

Rego, A. A. 1961. Sobre algunas especies do genero Litomosoides Chandler, 1931 (Nematoda, Filari- oidea). Memorias do Instituto Oswaldo Cruz 59: $1-9$.

Rutkowska, M. A. 1980. The helminthofauna of bats (Chiroptera) from Cuba. I. A review of nematodes and acanthocephalans. Acta Parasitologica Polonica 26:153-186.

Sandground, J. H. 1934. Description of a species of the filariid genus Litomosoides from Glossophaga soricina (Cheiroptera). Annals and Magazine of Natural History, Series 10, 14:595-599.

Scott, J. A., E. M. MacDonald, and B. Terman. 1951. A description of the stages in the life cycle of the filarial worm Litomosoides carinii. Journal of Parasitology 37:425-432.

Tibayrenc, M., O. Bain, and C. P. Ramachandran. 1979. Deux nouvelles Litomosa (Filarioidea) de chauves-souris. Bulletin du Muséum National d'Histoire Naturelle, Paris, 4e Série 1:183-189.

Wilson, D. E., and D. M. Reeder, eds. 1993. Mammals Species of the World: a Taxonomic and Geographic Reference, 2nd ed. Smithsonian Institution Press, Washington, D.C. 1206 pp.

Wilson, D. E., and A. Sandoval, eds. 1996. The Biodiversity of Southeastern Peru. The Smithsonian Institution Press, Washington, D.C. 679 pp. 